\title{
Modifiers and Readers of DNA Modifications and Their Impact on Genome Structure, Expression, and Stability in Disease
}

\author{
Anne K. Ludwig ${ }^{\dagger}$, Peng Zhang ${ }^{\dagger}$ and M. C. Cardoso* \\ Cell Biology and Epigenetics, Department of Biology, Technische Universität Darmstadt, Darmstadt, Germany
}

Cytosine base modifications in mammals underwent a recent expansion with the addition of several naturally occurring further modifications of methylcytosine in the last years. This expansion was accompanied by the identification of the respective enzymes and proteins reading and translating the different modifications into chromatin higher order organization as well as genome activity and stability, leading to the

OPEN ACCESS

Edited by:

Joanna Mary Bridger,

Brunel University London, UK

Reviewed by:

Abhiijt Shukla,

Harvard Medical School, USA

Jorg Tost,

Commissariat à l'Énergie Atomique-Institut de Génomique,

France

*Correspondence:

M. C. Cardoso

cardoso@bio.tu-darmstadt.de

tThese authors have contributed

equally to this work.

Specialty section:

This article was submitted to

Epigenomics and Epigenetics,

a section of the journal

Frontiers in Genetics

Received: 31 March 2016

Accepted: 06 June 2016

Published: 21 June 2016

Citation:

Ludwig AK, Zhang $P$ and

Cardoso MC (2016) Modifiers and Readers of DNA Modifications and Their Impact on Genome

Structure, Expression, and Stability in Disease. Front. Genet. 7:115. doi: 10.3389/fgene.2016.00115 hypothesis of a cytosine code. Here, we summarize the current state-of-the-art on DNA modifications, the enzyme families setting the cytosine modifications and the protein families reading and translating the different modifications with emphasis on the mouse protein homologs. Throughout this review, we focus on functional and mechanistic studies performed on mammalian cells, corresponding mouse models and associated human diseases.

Keywords: cytosine modifications, Dnmt, epigenetics, hydroxymethylcytosine, MBD, methylcytosine, mouse models, Tet

\section{DNA MODIFICATIONS AND MODIFIERS}

\section{Cytosine Modifiers: Dnmts}

In mammals, the modified cytosine was initially described by Hotchkiss (1948) and was further extensively studied since the 1970s (Razin and Cedar, 1977). Recently, evidence for methylation of adenine has been also reported in mammals (Koziol et al., 2016). Here, we will focus on cytosine modifications in mammals.

DNA cytosine methylation is catalyzed by DNA methyltransferases (Dnmts) that transfer a methyl group from $S$-adenosyl methionine to the fifth carbon of a cytosine residue to form 5methylcytosine $(5 \mathrm{mC})$. The majority of $5 \mathrm{mC}$ bases are present in $\mathrm{CpG}$ dinucleotides, however, non-CpG methylation was also observed especially in mouse embryonic stem cells (mESCs) and brain tissue (Guo et al., 2014). DNA methylation plays a major role in gene expression, cellular differentiation, genomic imprinting, X-inactivation, inactivation of transposable elements, and embryogenesis.

Cytosine methylation patterns are mainly established by de novo methyltransferases Dnmt3a, Dnmt3b and their regulatory unit Dnmt3l during early embryonic and germ cell development. Once the patterns are established, they are maintained throughout cell generations by Dnmt1 (Bestor et al., 1988; Li et al., 1992). Unlike Dnmt1 and Dnmt3a/3b, Dnmt2 is a RNA methyltransferase rather than a DNA methyltransferase (Okano et al., 1998; Yoder and Bestor, 1998; Goll et al., 2006). A summary of the mouse Dnmt protein family and their domains 
is shown in Figure $\mathbf{1}$ and a summary of the respective knockout mice phenotypes is shown in Table $\mathbf{1}$.

\section{De novo DNA Methylation}

Overexpression of Dnmt3a and Dnmt3b is capable of methylating both native and synthetic DNA with no preference for hemimethylated DNA (Okano et al., 1999). The domain structure for de novo methyltransferases Dnmt3a and Dnmt3b is similar, including a DNA binding domain PWWP domain (Qiu et al., 2002) and a C-terminal catalytic domain (Okano et al., 1999; Figure 1). However, several studies showed that the distribution and expression of Dnmt3a and Dnmt3b varies among cell types.

Dnmt3a is expressed relatively ubiquitously and two isoforms of Dnmt3a have been identified. One binds to euchromatic and the other to heterochromatic regions (Okano et al., 1998; Chen et al., 2002). Dnmt3a knockout mice developed to term and appeared to be normal at birth but most of the homozygous mutant mice became runted and died at about 4 weeks of age (Table 1).

Dnmt3b is highly expressed in embryonic implantation stages, as well as in stem cells and progenitor cells and is the major methyltransferase in early embryogenesis (Watanabe et al., 2002, 2004). Several isoforms were identified and among all isoforms only Dnmt3b1 and Dnmt3b2 possess DNA methyltransferase activity (Aoki et al., 2001). No viable Dnmt3b knockout mice were recovered at birth, further highlighting its functions in early embryogenesis (Table 1). The major substrates of Dnmt3a/3b are CpGs, but non-CpG methylation activity of Dnmt3a/3b was also detected (Aoki et al., 2001).

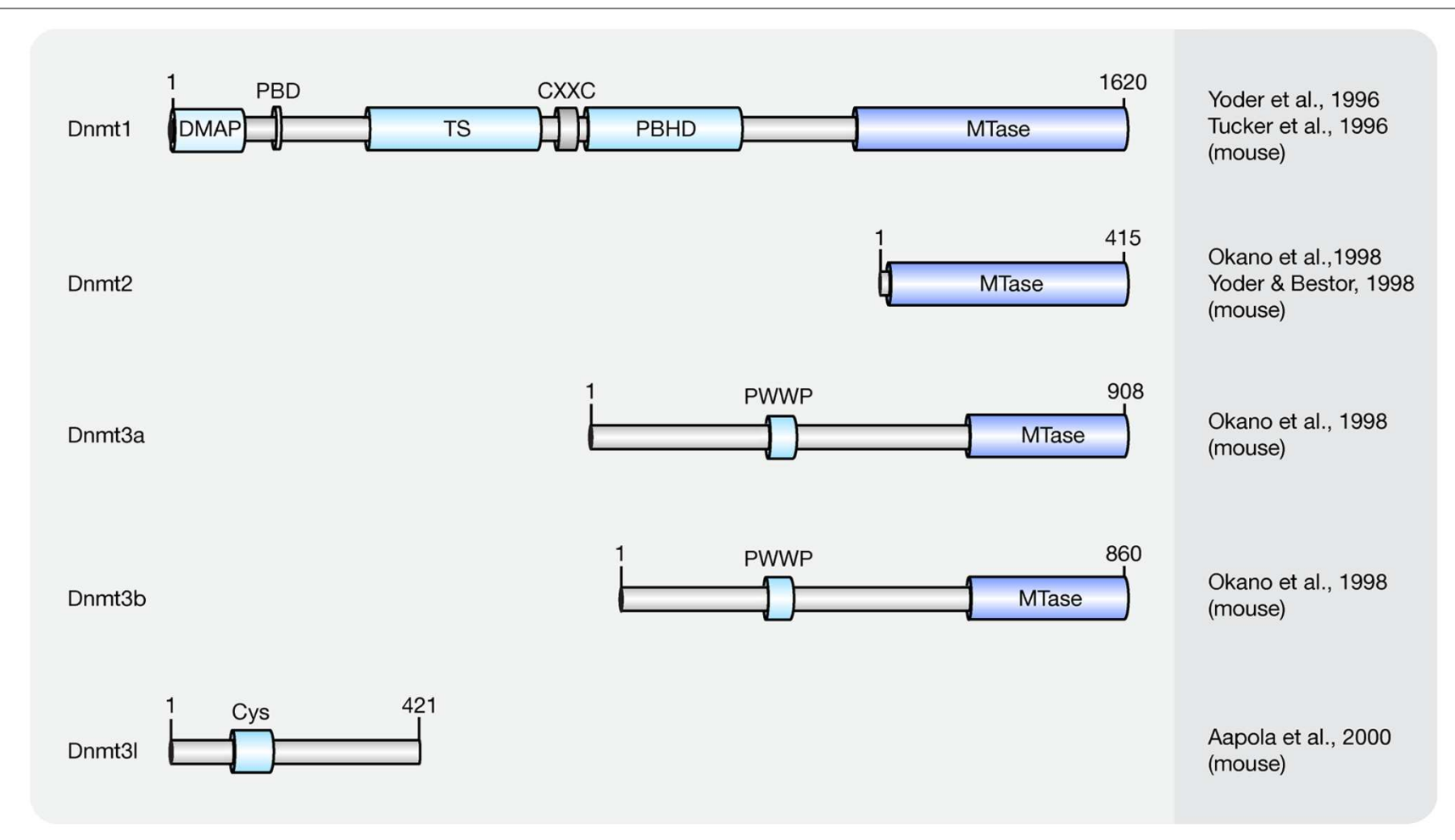

FIGURE 1 | Schematic representation of the Dnmt protein family. Shown are domain structures of mouse Dnmt proteins and the initial references. Numbers represent amino acid positions. DMAP, Dnmt1-associated protein binding domain; PBD, proliferating cell nuclear antigen (PCNA)-binding domain; TS, targeting sequence; CXXC, CXXC zinc finger domain; PBHD, polybromo-1 protein homologous domain; MTase, methyltransferase; PWWP,

proline-tryptophan-tryptophan-proline motif; Cys, cysteine-rich domain.

TABLE 1 | Phenotypes of initial Dnmt knockout mouse models.

\begin{tabular}{|c|c|c|}
\hline Genotype & Phenotype & Reference \\
\hline Dnmt1 null & Homozygous knockout Dnmt1 were stunted, delayed in development, and did not survive past midgestation & Li et al., 1992 \\
\hline Dnmt3a null & $\begin{array}{l}\text { Knockout mice developed to term and appeared to be normal at birth but most of homozygous mutant mice became } \\
\text { runted and died at about } 4 \text { weeks of age }\end{array}$ & Okano et al., 1999 \\
\hline Dnmt3b null & No viable Dnmt3b knockout mice were recovered at birth & Okano et al., 1999 \\
\hline Dnmt2 null & $\begin{array}{l}\text { Mice homozygous for this Trdmt1 (formerly Dnmt2) knock-out have abnormal RNA methylation while genomic DNA } \\
\text { methylation patterns are not detectably altered }\end{array}$ & Goll et al., 2006 \\
\hline Dnmt3/ null & $\begin{array}{l}\text { Disruption of Dnmt3/ caused azoospermia in homozygous males and heterozygous progeny of homozygous female } \\
\text { died before midgestation }\end{array}$ & Bourc'his et al., 2001 \\
\hline
\end{tabular}


Although Dnmt3l does not possess DNA methylation activity (Bourc'his et al., 2001), it strongly interacts with Dnmt3a/3b and enhances their methylation activity (Aapola et al., 2000; Suetake et al., 2004; Hu et al., 2008). However, high expression levels of Dnmt3l are found only in germ cells and early stage embryos but not in somatic cells (Watanabe et al., 2004) indicating that the methylation activity enhancement is cell type and developmental stage dependent. Disruption of Dnmt3l caused azoospermia in homozygous males and heterozygous progeny of homozygous female died before midgestation (Table 1).

\section{Maintenance DNA Methylation}

Dnmt1 has a preference for hemi-methylated DNA substrates (Song et al., 2011) and is the enzyme responsible for the maintenance of DNA methylation after DNA replication (Leonhardt et al., 1992). Homozygous knockout Dnmt1 mice were runted, delayed in development and did not survive past midgestation (Table 1). The major isoform of Dnmt1 in mice contains 1620 amino acids and includes an $\mathrm{N}$-terminal regulatory domain and a C-terminal catalytic domain (Tucker et al., 1996; Yoder et al., 1996). However, one isoform lacking the most $\mathrm{N}$-terminal 118 amino acids was shown to accumulate in mouse oocytes (Mertineit et al., 1998).

The Dnmt1-associated protein (DMAP) binding domain is located at the beginning of the N-terminus of Dnmt1 and it recruits DMAP1 to further maintain the heterochromatin state (Rountree et al., 2000). With the contribution of Uhrf1 [ubiquitin-like with plant homeodomain (PHD) and ring finger domains 1], Dnmt1 methylates hemi-methylated DNA generated upon DNA replication by a mechanism encompassing base flipping (Song et al., 2011, 2012).

In most mouse cells, Dnmt1 localizes to the cell nucleus. In fact, Dnmtl contains several functional nuclear localization sequences within its $\mathrm{N}$-terminal regulatory domain (Cardoso and Leonhardt, 1999). In early embryos (Cardoso and Leonhardt, 1999) and in post-mitotic neurons (Inano et al., 2000) though, it is retained in the cytoplasm. Although highly expressed in mouse embryos, the exclusion of Dnmt 1 from nuclei might inhibit DNA methylation conservation after DNA replication (Grohmann et al., 2005), implying that localization of Dnmt1 also regulates its methylation activity. Within the cell nucleus, the distribution of Dnmt1 is cell cycle dependent (Leonhardt et al., 1992). In G1-phase, it is diffusely distributed throughout the nucleoplasm. In early S-phase, its proliferating cell nuclear antigen (PCNA)binding domain (PBD) targets Dnmt1 to replication sites and in late S-phase, the targeting sequence (TS) further enhances Dnmt1 binding to replicating pericentromeric heterochromatin (Schermelleh et al., 2007; Schneider et al., 2013). In G2-phase, Dnmt1 is de novo loaded onto pericentromeric heterochromatin via a replication independent mechanism (Easwaran et al., 2004). Besides its PBD and TS domains, the polybromo-1 protein homologous domain (PBHD) is also involved in targeting Dnmt1 to replication foci (Liu et al., 1998). Between the TS and PBHD domains, a CXXC domain can be found in Dnmt1. The CXXC domain of Dnmtl occludes access of Dnmtl catalytic site to non-methylated CpGs and allows Dnmt1 to bind and specifically methylate hemi-methylated CpGs (Song et al., 2011).

\section{DNA Base Modifications}

The stable covalent $\mathrm{C}-\mathrm{C}$ bond formed between the methyl group and the cytosine is difficult to be directly removed and, therefore, $5 \mathrm{mC}$ is thought to be a long-lived epigenetic mark. After DNA replication, Dnmt1 association with the replication machinery ensures the maintenance of the methylation pattern onto the newly synthesized strand. Failure to do so, e.g., by retention in the cytoplasm as mentioned above, leads to gradual passive loss of DNA methylation over cell generations. DNA replication independent (active) loss of global DNA methylation was also observed in some biological processes such as reprogramming of the paternal genome after fertilization (Mayer et al., 2000) and development of primordial germ cells (PGC; Hajkova et al., 2002). The active loss of DNA methylation allows rapid reprogramming of the genome in a short time. Similar observations were made in post-mitotic neurons indicating that active loss of DNA methylation also occurs in somatic cells and might have important roles in the regulation of gene expression (Martinowich et al., 2003).

For several decades, scientists have been interested in identifying pathways or proteins involved in the active loss of DNA methylation. Lacking the evidence to show that $\mathrm{C}-\mathrm{C}$ bonds can be directly broken in mammals, multistep processes have been proposed to be involved in the active removal of DNA methylation marks. In 1972, several additional modifications of cytosines were described in rat, mouse, and frog brain tissue including 5-hydroxymethylcytosine $(5 \mathrm{hmC}), 5$-formylcytosine (5fC), 5-carboxylcytosine ( $5 \mathrm{caC})$, and 5-hydroxymethyluracil (5hmU; Penn et al., 1972; Figure 2). However, these modifications were considered to be oxidative damage products of DNA (de Rojas-Walker et al., 1995; TardyPlanechaud et al., 1997). Three decades later, $5 \mathrm{hmC}$ was rediscovered in mouse brain tissue (Kriaucionis and Heintz, 2009) and embryonic stem cells (ESCs; Tahiliani et al., 2009). Furthermore, a family of proteins (ten-eleven translocation, TET) was identified that oxidize $5 \mathrm{mC}$ to $5 \mathrm{hmC}$ both in humans (Tahiliani et al., 2009) and mice (Ito et al., 2010). TET1 was first described in 2003 as a fusion partner of the mixed lineage leukemia (MLL) gene in acute myeloid leukemia (AML; Lorsbach et al., 2003) and 6 years later it was re-discovered as an oxygenase, which can convert $5 \mathrm{mC}$ to $5 \mathrm{hmC}$ (Tahiliani et al., 2009). Further studies showed that Tet proteins also convert $5 \mathrm{hmC}$ to $5 \mathrm{fC}$ and $5 \mathrm{caC}$ (Ito et al., 2011; Pfaffeneder et al., 2011).

Deaminases such as Aid and Apobec can recognize $5 \mathrm{mC}$ and $5 \mathrm{hmC}$ and further convert $5 \mathrm{mC}$ to thymine $(\mathrm{T})$ and $5 \mathrm{hmC}$ to $5 \mathrm{hmU}$. Although the deaminase activity is quite low, it is still a possible pathway for DNA demethylation (Guo et al., 2011). In addition, Tets were also shown to oxidize $\mathrm{T}$ to $5 \mathrm{hmU}$ in mESCs (Pfaffeneder et al., 2014), which additionally leads to loss of DNA methylation. The oxidation products like $5 \mathrm{fC}, 5 \mathrm{caC}$, and $5 \mathrm{hmU}$ can be recognized and excised by the glycosylases Tdg (Maiti and Drohat, 2011) and Neil (Muller et al., 2014) to create an abasic site on DNA, which is further repaired by enzymes of the base excision repair (BER) pathway. In addition to $\mathrm{Tdg}, 5 \mathrm{hmU}$ can also be recognized by other glycosylases like Mbd4 (Hashimoto et al., 2012b) and Smug1 (Kemmerich et al., 2012). Accordingly, a combination of oxidation, deamination 


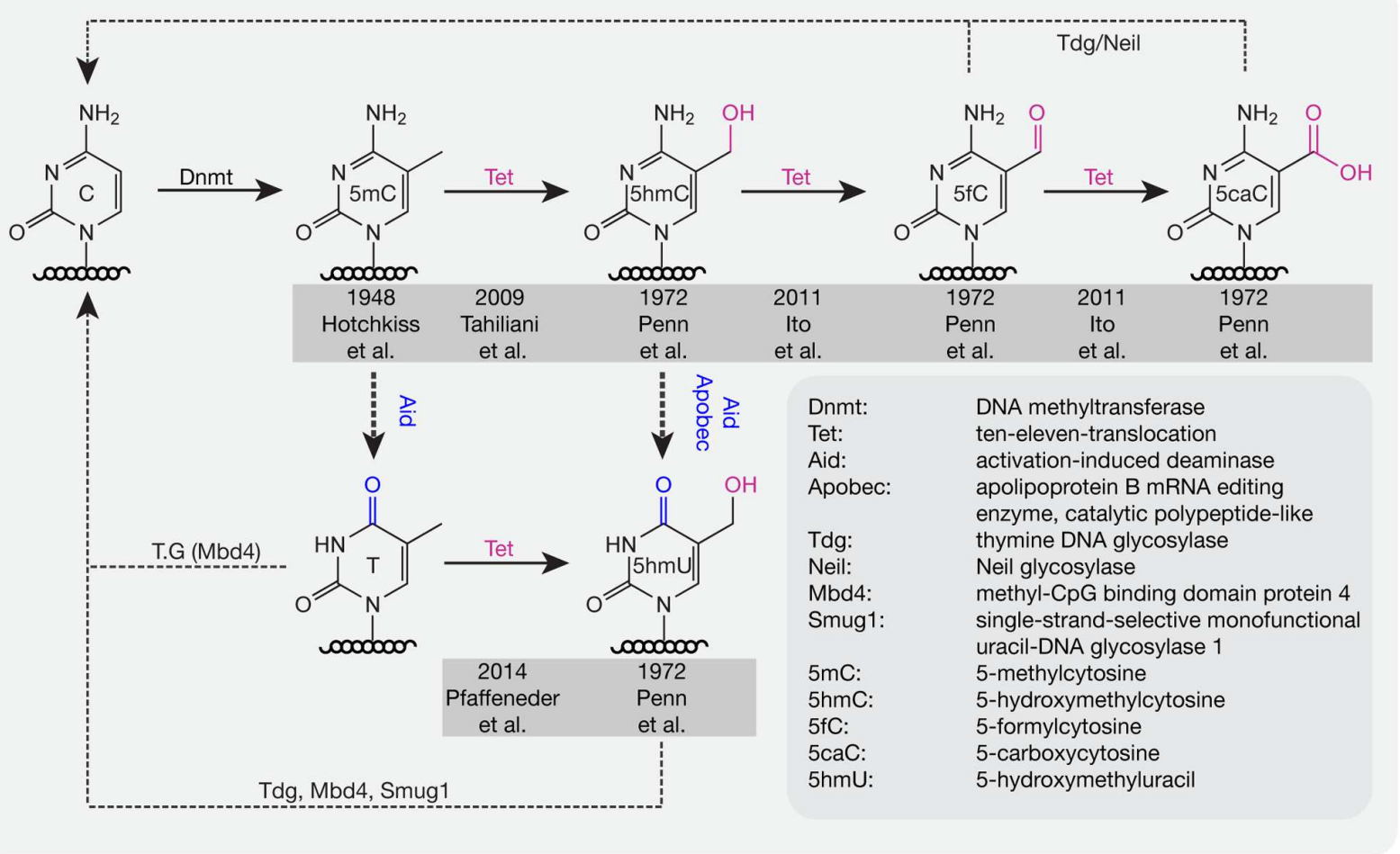

FIGURE 2 | DNA base modifications with respective enzymes. Dnmts catalyze the addition of a methyl group to cytosine bases. Tet proteins oxidize methylated cytosines to $5 \mathrm{hmC}, 5 \mathrm{fC}$, and $5 \mathrm{caC}$ in an iterative manner. $5 \mathrm{mC}$ and $5 \mathrm{hmC}$ can be further deaminated by Aid/Apobec to T and $5 \mathrm{hmU}$. T, $5 \mathrm{hmU}, 5 \mathrm{fC}$, and $5 \mathrm{caC}$ can be removed by the indicated glycosylases. Initial references are indicated.

and BER might contribute to the active removal of DNA methylation. In mouse zygotes, the decrease of $5 \mathrm{mC}$ and increase of $5 \mathrm{hmC}$ suggests that $5 \mathrm{hmC}$ might be an intermediate of DNA methylation removal. However, recent studies showed that loss of $5 \mathrm{mC}$ mainly happens before S-phase, whereas gain of 5 hmC occurred after DNA replication (Amouroux et al., 2016), indicating that besides the conversion of $5 \mathrm{mC}$ to $5 \mathrm{hmC}$, other pathways might contribute to methylation removal before DNA replication in mouse zygotes.

\section{Methylcytosine Modifiers}

Until now three members of the Tet protein family named Tet1 (mouse homolog of human TET1), Tet2 (mouse homolog of human TET2), and Tet3 (mouse homolog of human TET3) have been identified in mice and humans. All three Tets share a conserved $\mathrm{C}$-terminal catalytic domain including a cysteine-rich and a double-stranded $\beta$-helix (DSBH) domain, which belong to the cupin-like dioxygenase superfamily; and exhibit iterative iron- and oxoglutarate-dependent oxidation activity (Figure 3).

\section{Tissue and Genome-Wide Distribution of Tet}

During mouse embryo development, Tet3 is highly expressed in oocytes and zygotes. Female mice depleted of Tet 3 in the germ line showed severely reduced fecundity and their heterozygous mutant offspring lacking maternal Tet3 suffer an increased incidence of developmental failure. Since Tet1, Tet2 as well as
Tet 1 and Tet 2 double knockout mice are viable, this suggests that Tet 1 and Tet 2 are not essential for mouse development (Table 2).

Tet-mediated $5 \mathrm{mC}$ to $5 \mathrm{hmC}$ conversion is though involved in reprogramming the paternal genome ( $\mathrm{Gu}$ et al., 2011; Iqbal et al., 2011; Wossidlo et al., 2011; Zhang et al., 2012) and also in reprogramming donor cell DNA during somatic cell nuclear transfer (Gu et al., 2011). In addition, HIV-1 Vpr binding protein (VprBP)-mediated monoubiquitylation promotes Tet binding to chromatin and enhances $5 \mathrm{hmC}$ formation (Nakagawa et al., 2015) in mouse embryos. This process is involved in female germ cell development and genome reprogramming in zygotes ( $\mathrm{Yu}$ et al., 2013).

During PGC reprogramming, Tet1 and Tet2 are highly expressed (Hackett et al., 2013). However, genome-wide DNA methylation removal is unaffected by the absence of Tet1 and Tet2 and, thus, $5 \mathrm{hmC}$, indicating that the first comprehensive $5 \mathrm{mC}$ loss does not involve $5 \mathrm{hmC}$ formation. Instead Tet 1 and Tet2 have a locus specific role in shaping the PGC epigenome during subsequent development (Vincent et al., 2013). Further studies showed that Tet1 has a critical role in the erasure of genomic imprinting (Yamaguchi et al., 2013) and it controls meiosis by regulating meiotic gene expression (Yamaguchi et al., 2012).

In mESCs, both Tet1 and Tet2, as well as their oxidation product $5 \mathrm{hmC}$ are highly abundant (Ito et al., 2010). While Tet2 preferentially acts on gene bodies, Tet1 preferentially acts on 


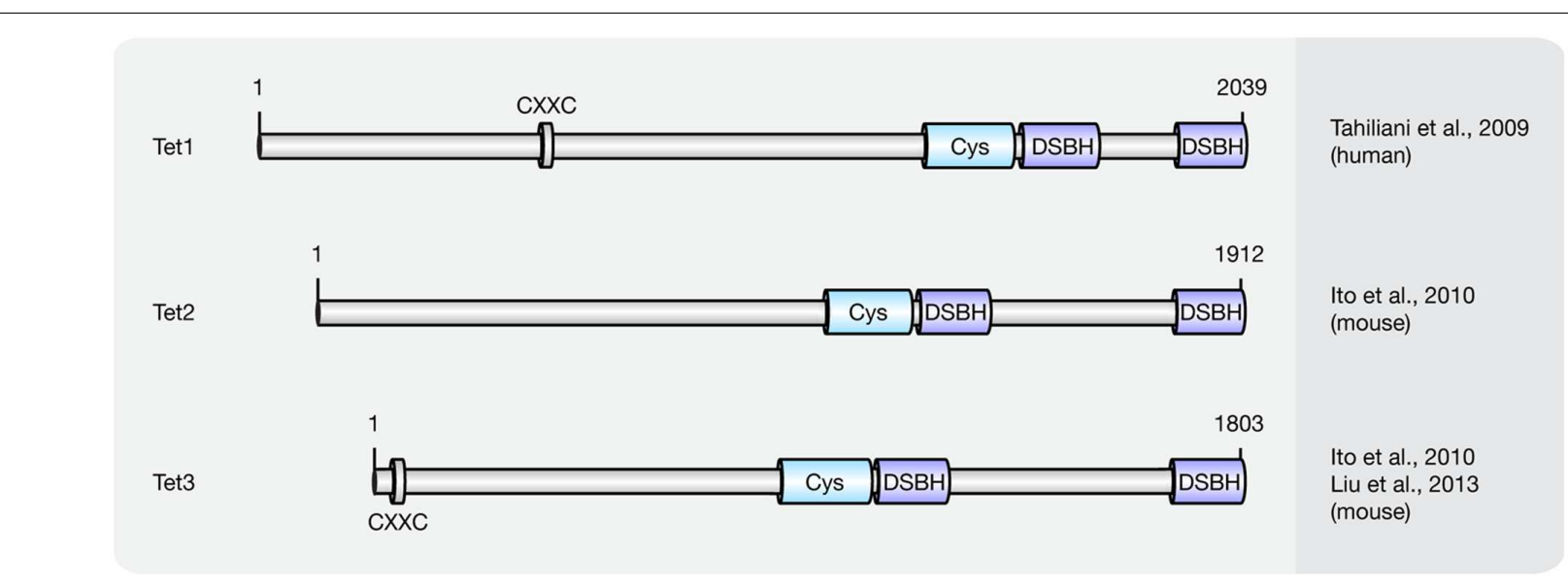

FIGURE 3 | Schematic representation of the Tet protein family. Shown are domain structures of mouse Tet proteins and the initial references. Numbers represent amino acid positions. CXXC, CXXC zinc finger domain; Cys, cysteine-rich domain; DSBH, double-stranded $\beta$-helix.

TABLE 2 | Phenotypes of initial Tet knockout mouse models.

\begin{tabular}{|c|c|c|}
\hline Genotype & Phenotype & Reference \\
\hline Tet1 null & Mice are viable, fertile, and grossly normal though some mutant mice have a slightly smaller body size at birth & Dawlaty et al., 2011 \\
\hline Tet1 null & Animals exhibited abnormal hippocampal long-term depression and impaired memory extinction & $\begin{array}{l}\text { Rudenko et al., 2013; } \\
\text { Zhang et al., } 2013\end{array}$ \\
\hline Tet2 null & $\begin{array}{l}\text { Approximately one-third of Tet2 }-/- \text { and } 8 \% \text { of } T e t 2^{+/-} \text {mice died within } 1 \text { year of age because of the development of } \\
\text { myeloid malignancies resembling characteristics of chronic myelomonocytic leukemia, myeloproliferative disorder-like } \\
\text { leukemia, and myelodysplastic syndrome }\end{array}$ & Li et al., 2011 \\
\hline Tet3 null & $\begin{array}{l}\text { Female mice depleted of Tet3 in the germ line show severely reduced fecundity and their heterozygous mutant offspring } \\
\text { lacking maternal Tet3 suffer an increased incidence of developmental failure. Oocytes lacking Tet3 also seem to have a } \\
\text { reduced ability to reprogram the injected nuclei from somatic cells }\end{array}$ & Gu et al., 2011 \\
\hline Tet1 and Tet2 null & $\begin{array}{l}\text { Double deficient mice had reduced } 5 \mathrm{hmC} \text { and increase } 5 \mathrm{mC} \text { levels and abnormal methylation at various imprinted loci. } \\
\text { Animals of both sexes were fertile with females having smaller ovaries and reduced fertility }\end{array}$ & Dawlaty et al., 2014 \\
\hline
\end{tabular}

promoters and transcription start sites (TSS; Huang et al., 2014). Tet 1 and Tet 2 double knockout ESCs remained pluripotent, but were depleted of $5 \mathrm{hmC}$ and caused developmental defects in chimeric embryos (Dawlaty et al., 2014). During somatic reprogramming, Tet 2 is required for $5 \mathrm{hmC}$ formation at the Nanog locus (Doege et al., 2012). Further studies showed that the recruitment of Tet1 by Nanog facilitates the expression of a subset of reprogramming target genes, such as Oct4 (Costa et al., 2013). Accordingly, Tet1 can replace Oct4 during somatic cell reprogramming in conjunction with Sox2, Klf4, and c-Myc (Gao et al., 2013). The data above indicate that Tet-mediated $5 \mathrm{hmC}$ formation is not only important for ESCs differentiation but also for somatic reprogramming.

In mouse brain, $5 \mathrm{hmC}$ is a constituent of nuclear DNA (Kriaucionis and Heintz, 2009). Tet1 plays an important role in regulating neural progenitor cell (NPC) proliferation in adult mouse brain (Zhang et al., 2013) and is critical for neuronal activity-regulated gene expression and memory extinction (Table 2; Rudenko et al., 2013).

\section{Regulation of Tet Activity}

Similar to Dnmt1, Tet proteins use a base flipping mechanism to oxidize $5 \mathrm{mC}$, which includes binding of DNA by a Watson-Crick polar hydrogen and van der Waals interactions, flipping out $5 \mathrm{mC}$
(Hu et al., 2013; Hashimoto et al., 2014) and oxidation of $5 \mathrm{mC}$ to $5 \mathrm{hmC}$ (Hashimoto et al., 2015; Hu et al., 2015). Although Tet proteins successively oxidize $5 \mathrm{mC}$ to $5 \mathrm{caC}$, recent experimental data showed that, in comparison with $5 \mathrm{hmC}$ and $5 \mathrm{fC}, 5 \mathrm{mC}$ is the preferential substrate for Tet2 (Hu et al., 2015). This preference was further confirmed by computer simulations (Lu et al., 2016). In cultured cells, the majority of genomic $5 \mathrm{hmC}$ nucleotides are stable (Bachman et al., 2014), indicating that $5 \mathrm{hmC}$ is not only involved in loss of DNA methylation, but represents an additional stable epigenetic mark. The global content of $5 \mathrm{hmC}$ varies in mouse tissues, does not correlate with $5 \mathrm{mC}$ content and rapidly decreases as the cells adapt to cell culture conditions (Nestor et al., 2012). The cell-, tissue-, and developmental stagespecific distribution of $5 \mathrm{hmC}$ indicates that the conversion of $5 \mathrm{mC}$ to $5 \mathrm{hmC}$ is highly regulated.

Although the N-terminal domain (NTD) of Tet proteins was shown to be dispensable for their catalytic activity, it was shown to possess regulatory functions. A CXXC domain, which usually binds specifically to unmethylated CpGs can be found in the N-terminus of Tet1 and Tet3 (Liu et al., 2013). While the CXXC domain of Tet1 cannot bind to DNA in vitro (Frauer et al., 2011b), it binds to unmodified C, $5 \mathrm{mC}$ - or $5 \mathrm{hmC}$-modified CpGs in vivo (Zhang et al., 2010; Xu Y. et al., 2011). Moreover, binding of the CXXC domain to DNA was shown to control DNA methylation 
levels by preventing unwanted DNA methyltransferase activity in ESCs (Xu Y. et al., 2011) or aberrant methylation spreading into CpG islands (CGIs) in differentiated cells (Jin et al., 2014). The CXXC domain of Xenopus Tet3 recognizes non-methylated cytosines in either CpG or non-CpG context, and it is critical for specific Tet 3 targeting (Xu et al., 2012). Although Tet 2 proteins do not have a CXXC domain, recent studies showed that the ancestral CXXC domain of Tet 2 is encoded by a distinct gene named Idax. Unlike the CXXC domain of Tet1 and Tet3, the CXXC domain of Idax binds unmethylated CpGs. Through direct protein-protein interactions of Tet 2 and Idax, Tet 2 is recruited to DNA. Furthermore, Tet 2 is degraded by caspase activation, which is triggered by the CXXC of Idax (Ko et al., 2013).

Two parts of the DSBH domain are connected by a potential regulatory spacer region. Although the spacer region was shown to be dispensable for $5 \mathrm{mC}$ catalytic activity (Hu et al., 2013), posttranslational modifications (PTMs), such as phosphorylation and O-GlcNAcylation were observed in the spacer region (Bauer et al., 2015) indicating that it might exhibit regulatory functions. O-GlcNAc transferase (Ogt) directly interacts with Tet proteins and consequently Tet proteins are GlcNAcylated. The GlcNAcylation does not affect the hydroxylation activity of Tet2 and Tet3, rather Tet 2 and Tet 3 were shown to promote Ogt activity (Deplus et al., 2013) by enhancing the localization of Ogt to chromatin (Chen et al., 2013; Ito et al., 2014). However, it was shown that Ogt drives Tet 3 out of the nucleus further affecting its activity on DNA (Zhang et al., 2014). In mESCs, Ogt is recruited to unmethylated $\mathrm{CpG}$ promoters in a Tet1-dependent manner (Vella et al., 2013). In addition to PTMs, mutations within the spacer region of Tet 2 were observed in myelodysplastic syndrome (MDS), thus further highlighting the importance of this region (Ko et al., 2010).

In vivo, besides PTMs, Tet activity is regulated by proteinprotein interactions, such as with Sin3a. In mESCs, the interaction between $\operatorname{Sin} 3 \mathrm{a}$ and Tet1 allows $\operatorname{Sin} 3 \mathrm{a}$ to repress a subset of Tet1 target genes (Williams et al., 2011). In mouse zygotes, Tet3-mediated $5 \mathrm{mC}$ to $5 \mathrm{hmC}$ conversion is involved in reprogramming of the paternal but not the maternal genome although they share the same cytoplasm (Mayer et al., 2000). The resistance of the maternal genome to reprogramming is achieved by a protein named developmental pluripotency associated 3 (Dppa3, or PGC7). Dppa3 binds to histone H3K9me2 (Nakamura et al., 2012) and interacts with Tet3 further blocking the activity of Tet3 (Bian and Yu, 2014). Dazl, an RNA-binding protein known to play a key role in germ cell development, was shown to enhance Tet1-mediated $5 \mathrm{mC}$ to $5 \mathrm{hmC}$ conversion by enhancing Tet 1 protein translation (Welling et al., 2015). In addition, growth arrest and DNA damage inducible protein 45 (Gadd45) interacts with Tet1 and Tdg and promotes loss of DNA methylation by enhancing $5 \mathrm{fC} / 5 \mathrm{caC}$ removal (Kienhöfer et al., 2015; Li et al., 2015).

Finally, Tet-mediated $5 \mathrm{mC}$ to $5 \mathrm{hmC}$ conversion was shown to be regulated by Tet cofactors. 2-Ketoglutarate (2-KG), one of the cofactors for Tet oxidation is produced by isocitrate dehydrogenase $1 / 2(\operatorname{Idh} 1 / 2)$ in vivo. However, mutated Idh1/2 produce 2-hydroxyglutarate, a competitive inhibitor of 2-KG, which can further inhibit $5 \mathrm{mC}$ to $5 \mathrm{hmC}$ conversion (Konstandin et al., 2011). Vitamin C is a potential cofactor for Tet-mediated oxidation and was shown to enhance Tet activity, which leads to increased global 5hmC in ESCs (Blaschke et al., 2013). ATP was also shown to be involved in regulating Tet activity. In vitro, the reaction of Tet-mediated $5 \mathrm{mC}$ to $5 \mathrm{caC}$ can be enhanced by addition of ATP (He et al., 2011).

\section{Hydroxymethylcytosine maintenance}

Dnmt1 recognizes hemi-mC DNA and methylates the nascent DNA strand after replication during the S-phase of the cell cycle. However, in vitro studies showed a 60 -fold decreased binding ability of Dnmtl to hemi-hmC DNA compared to hemimC DNA (Hashimoto et al., 2012a), indicating that hemi-hmC DNA might not be a substrate for Dnmt1. Previous studies showed that Np95 can recognize $5 \mathrm{hmC}$ and bind to hemihmC DNA (Frauer et al., 2011a), indicating that Np95 might target Dnmtl to hemi-hmC containing replication forks to maintain hmC after DNA replication. In addition, Dnmt3a and Dnmt3b recognize hemi-hmC DNA (Hashimoto et al., 2012a) and are necessary for methylation maintenance at repeat genomic elements (Chen et al., 2003) suggesting Dnmt3a/3b might play a role in maintaining $5 \mathrm{hmC}$ after DNA replication in repeat elements.

In vivo, the majority of $5 \mathrm{hmC}$ is present in $\mathrm{CpG}$ dinucleotides. However, $5 \mathrm{hmC}$ has also been observed in non-CpG context, especially in gene bodies (Pastor et al., 2011; Xu Y. et al., 2011). One important role of $\mathrm{CpG}$ methylation in gene promoter regions is the repression of gene expression by directly or indirectly preventing interactions between promoter and transcription factors. Hydroxymethylated CpGs might affect binding of transcription factors and/or $5 \mathrm{mC}$ readers to DNA.

\section{DNA MODIFICATION READERS}

In mammals, the methylome is specifically read by a variety of proteins known as methyl-CpG binding proteins (MBPs), which based on structural features are further classified into three main families: the methyl-CpG binding domain (MBD) protein family (Lewis et al., 1992; Cross et al., 1997; Hendrich and Bird, 1998; Hendrich and Tweedie, 2003; Laget et al., 2010; Baymaz et al., 2014), the Kaiso protein family (Daniel and Reynolds, 1999; Filion et al., 2006), and the SET and RING (really interesting new gene) finger associated (SRA) domain protein family (Hopfner et al., 2000; Mori et al., 2002). While initially identified as 5mC binding proteins, recent studies indicate that a distinct and dynamic set of MBPs binds the Tet oxidation product $5 \mathrm{hmC}$ during differentiation (Figure 4; Frauer et al., 2011a; Mellen et al., 2012; Spruijt et al., 2013). Through further interactions with multiple protein partners, MBPs provide a link between cytosine derivatives and functional chromatin states in a temporally and spatially regulated fashion.

\section{MBD Protein Family}

Presently, the MBD protein family consists of eleven members (Mecp2, Mbd1-6, SETDB1, SETDB2, TIP5/BAZ2A, and BAZ2B; Lewis et al., 1992; Cross et al., 1997; Hendrich and Bird, 1998; 


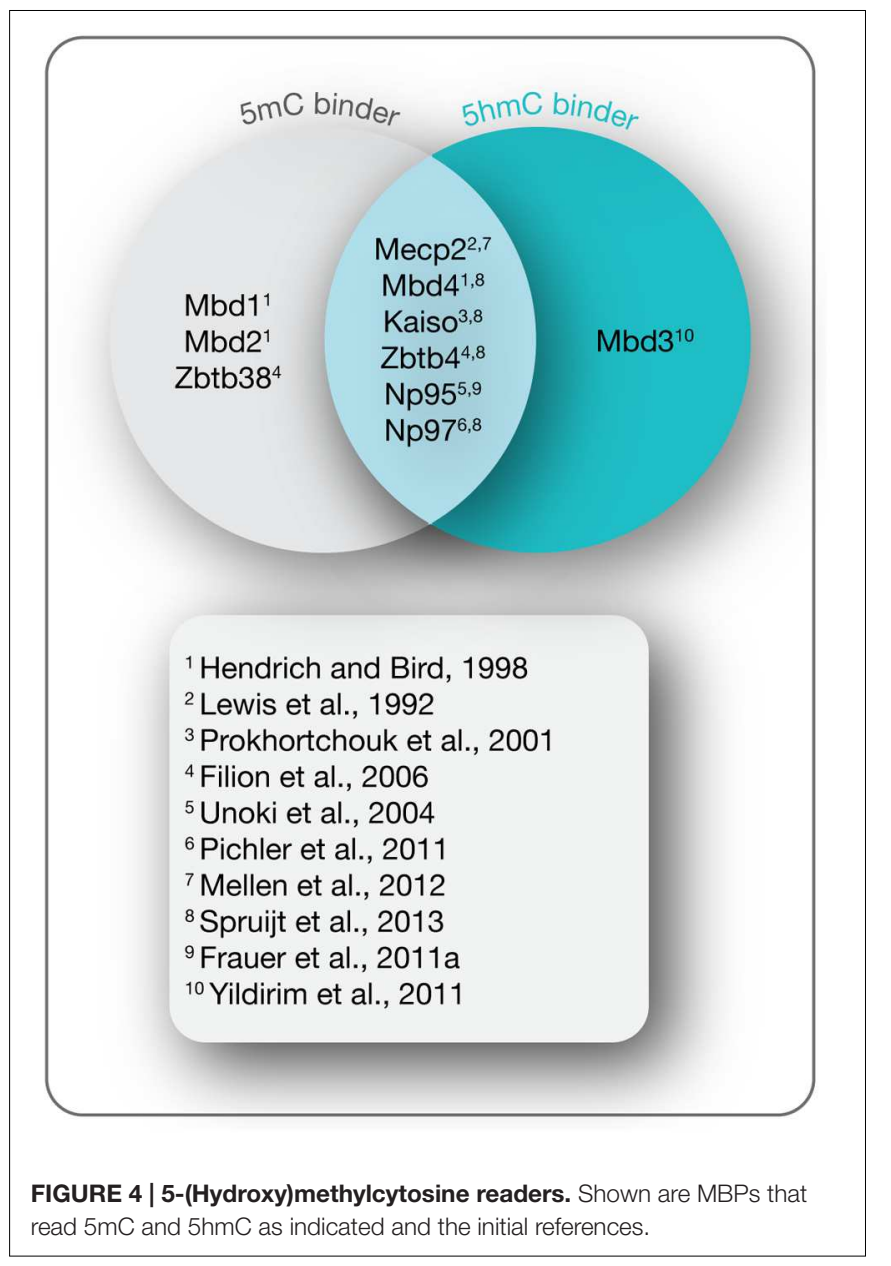

Hendrich and Tweedie, 2003; Laget et al., 2010; Baymaz et al., 2014). All of them share a common protein motif, the 7085 amino acids long MBD, which enables some, but not all family members, to selectively bind to single methylated CpG dinucleotides. With the exception of Mbd2 and Mbd3, MBD proteins bear little resemblance outside their MBD (Hendrich and Bird, 1998). Instead, MBD proteins comprise several distinct domains that confer unique DNA binding, as well as other functional features. Since this review covers DNA (hydroxy)methylation-dependent processes, we will thereafter focus on MBD family members (Figure 5) capable of binding to (hydroxy)methylated $\mathrm{CpG}$ dinucleotides, i.e., methyl-CpG binding protein 2 (Mecp2) and methyl-CpG binding domain proteins 1-4 (Mbd1-4).

\section{Mecp2}

The first protein described to selectively recognize and bind single, symmetrically methylated CpG dinucleotides was Mecp2 (Lewis et al., 1992). It is abundantly expressed in the central nervous system with the highest protein levels in post-mitotic neurons (Akbarian et al., 2001; Traynor et al., 2002; Jung et al., 2003). Of the two alternatively spliced isoforms (Mecp2 e1 and e2), which differ in their N-terminus, Mecp2 e2 was first identified and is, therefore, best characterized (Kriaucionis and
Bird, 2004; Mnatzakanian et al., 2004). Although both isoforms distribute differently in developing and post-natal mouse brains, no functional differences have been identified so far (Dragich et al., 2007).

Both Mecp2 variants include two functionally characterized domains, the MBD and the transcriptional repression domain (TRD). While the MBD proved sufficient to direct specific binding to methylated cytosines (Nan et al., 1993), the TRD was originally identified as the region required for transcriptional repression in vitro and in vivo (Lewis et al., 1992; Nan et al., 1997; Jones et al., 1998; Kaludov and Wolffe, 2000). Circular dichroism and protease digestion analysis revealed that outside these functional domains the full-length protein is largely devoid of secondary structure (Adams et al., 2007). With almost 60\% unstructured regions, Mecp2 is reckoned among the intrinsically disordered proteins, which often undergo a disorder-to-order transition upon binding to other macromolecules (Adams et al., 2007). Indeed, recent studies demonstrate that Mecp2 gains secondary structure and acquires substantial thermal stabilization upon binding to DNA (Ghosh et al., 2010). Unlike its name implies DNA binding is, however, not solely mediated via its $5 \mathrm{mC}$ specific MBD. Instead, as indicated by the release of Mecp2 upon salt extraction, regions outside the MBD contribute to the overall binding energy through electrostatic interactions (Meehan et al., 1992). As shown by electrophoretic mobility shift assays (EMSAs), these sequence-unspecific DNA binding motifs include the TRD and, based on their relative location to the MBD and TRD, the so-called intervening domain, as well as the C-terminal domain alpha (Ghosh et al., 2010). The NTD of Mecp2 in contrast, contributes indirectly to the overall binding affinity by enhancing the methylation specificity of the MBD through conformational coupling (Ghosh et al., 2010). An analog synergistic increase in DNA binding efficiency was observed through interdomain interactions between the TRD and the C-terminal part of the protein (Ghosh et al., 2010). Similar to the NTD, the C-terminal domain beta (CTD beta) does not directly interact with DNA (Ghosh et al., 2010). Nevertheless, the overall chromatin binding efficiency was lost upon its deletion (Nikitina et al., 2007b). Consistent with this, the CTD beta induced moderate and reproducible shifts with nucleosomal arrays, but not with naked DNA (Ghosh et al., 2010), suggesting that the most C-terminal 192 residues of Mecp2 harbor a chromatin interaction surface (Nikitina et al., 2007b). Indeed, Mecp2 has been shown to interact with histone $\mathrm{H} 3$ and, similar to the linker histone $\mathrm{H} 1$, binds to nucleosomes close to the linker DNA entry-exit site (Nikitina et al., 2007b). As a result, the entering and exiting linker DNA segments are brought in close proximity to form a stem-like motif (Nikitina et al., 2007a), which bears strong resemblance to structures induced by H1 (Hamiche et al., 1996; Bednar et al., 1998). The modes of chromatin compaction, however, differ significantly from each other. While histone $\mathrm{H} 1$ arranges nucleosomes and linker DNA into regular zigzag-shaped chromatin fibers (Woodcock, 2006), Mecp2 forms highly compacted globular structures in vitro due to its multiple DNA and chromatin binding domains (Georgel et al., 2003). Accordingly, Mecp2 was shown to induce clustering of pericentric heterochromatin in a dose-dependent manner 


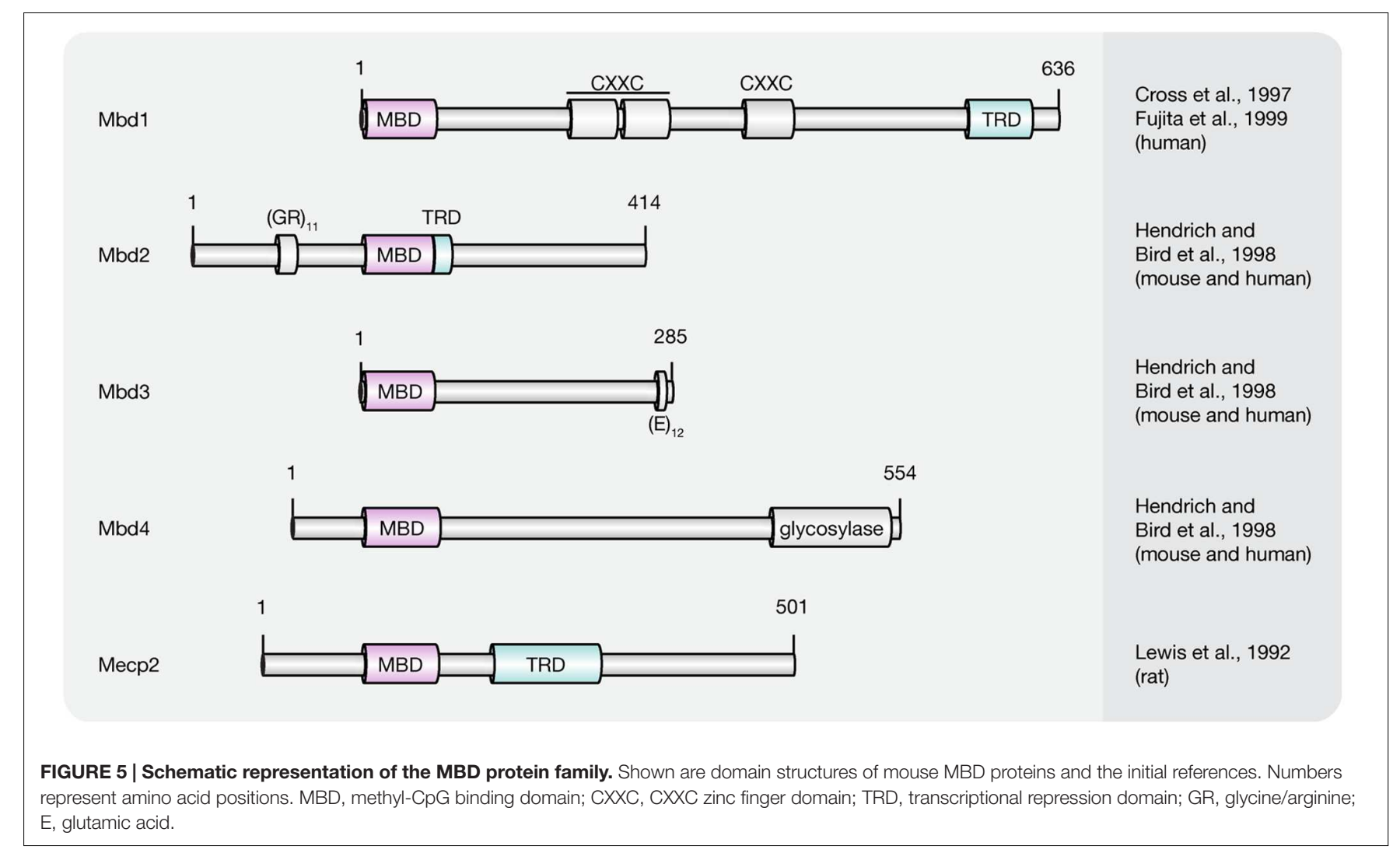

in vivo to establish a locally repressive chromatin environment (Brero et al., 2005; Agarwal et al., 2011). More recently, Szulwach et al. (2011) provided evidence that binding of Mecp2 to methylated $\mathrm{CpG}$ dinucleotides may protect $5 \mathrm{mC}$ against Tetmediated oxidation thereby preventing reactivation of silenced genes. The underlying mechanism, however, has so far not been described.

An additional level of regulation is achieved through various protein-protein interactions. While direct homo- and heterointeractions of Mecp2 and Mbd2 were shown to cross-link chromatin fibers (Becker et al., 2013), physical associations of Mecp2 with the transcriptional co-repressor Sin3a and histone deacetylase 2 (HDAC2) via its TRD contribute to the global heterochromatin architecture through histone hypoacetylation (Jones et al., 1998; Nan et al., 1998). Consequently, Mecp2 deficiency was demonstrated to result in global changes in neuronal chromatin architecture, elevated histone acetylation levels, and increased transcriptional noise in a DNA methylationdependent manner (Skene et al., 2010; Cohen et al., 2011). A number of other repressive protein partners of Mecp2 have been identified including the co-repressors c-Ski (Kokura et al., 2001), CoREST (Lunyak et al., 2002), and NCoR/SMRT (Stancheva et al., 2003), as well as DNA methyltransferase Dnmt1 (Kimura and Shiota, 2003) and H3K9 methyltransferase (Fuks et al., 2003).

Both, binding of Mecp2 to DNA, as well as interactions with protein partners are affected by PTMs. Neuronal activity induced phosphorylation and dephosphorylation of Mecp2 was shown to modulate its association with promoters of specific genes, as well as with interaction partners (reviewed in $\mathrm{Li}$ and Chang, 2014). More recently, poly(ADP-ribosyl)ation of Mecp2 in mouse brain tissue was reported, which anticorrelated with its chromatin binding affinity and clustering ability (Becker et al., 2016). Furthermore, ubiquitylation (Gonzales et al., 2012), SUMOylation (Cheng et al., 2014), acetylation (Zocchi and Sassone-Corsi, 2012), and methylation (Jung et al., 2008) were shown to substantially contribute to the functional versatility of Mecp2.

Another unanticipated level of functional complexity was demonstrated by recent work of Spruijt et al. (2013) who identified Mecp2 as reader of $5 \mathrm{hmC}$ in mESC by quantitative mass-spectrometry-based proteomics. Moreover, independent studies of Mellen et al. (2012), revealed Mecp2 as the major $5 \mathrm{hmC}$-binding protein in mouse brain, which moreover turned out to bind both, 5hmC- and $5 \mathrm{mC}$-containing substrates with similar affinity.

Finally, chip-chip analysis using antibodies against MECP2 in a human neuronal cell line demonstrated that around twothird of strongly MECP2 bound promoters were transcriptionally active (Yasui et al., 2007). Subsequent analysis of gene expression patterns in Mecp2 knockout and overexpressing mice concurred that Mecp2 functions as an activator as well as a repressor of transcription (Chahrour et al., 2008).

Hence, the traditional view of Mecp2 as a $5 \mathrm{mC}$-dependent transcriptional silencer may be incomplete and its biology appears far more complicated than previously assumed. 
Both, male and female mice lacking Mecp2 (Table 3) developed an uncoordinated gait and reduced spontaneous movement between 3 and 8 weeks of age and most died between 6 and 12 weeks (Chen et al., 2001; Guy et al., 2001). Furthermore, most animals developed hind limb clasping, irregular breathing, misaligned jaws and uneven wearing of teeth. Mutant brains were reduced in weight, however, no structural abnormalities or signs of neurodegeneration were detected, suggesting that stability of brain function, not brain development per se, is impaired in the absence of Mecp2. Consistent with this hypothesis, re-expression of the Mecp2 gene in Mecp $2^{\text {lox-Stop/y }}$ mice proved sufficient to reverse the neurological symptoms of Rett syndrome (RTT), indicating that Mecp2-deficient neurons develop normally and are not irreversibly damaged (Guy et al., 2007). Further microarray analyses revealed that knockout of Mecp2 implicates only minor changes in gene expression (Tudor et al., 2002). Subsequent studies demonstrating increased expression restricted to noncoding RNA in brain of Mecp2-deficient mice (Muotri et al., 2010; Skene et al., 2010), indicated that Mecp2 may not act as a gene-specific transcriptional repressor, but might instead dampen transcriptional noise genome-wide in a DNA methylation-dependent manner (Skene et al., 2010). Accordingly, expression of repetitive elements (Muotri et al., 2010; Skene et al., 2010) as well as retrotransposition of LINE1 was increased in brain of Mecp2-deficient mice (Muotri et al., 2010).

\section{Mbd1}

Mbd1, initially termed PCM1, is expressed in somatic cells and represents the largest member of the MBD family (Cross et al., 1997; Hendrich and Bird, 1998). Similar to Mecp2, Mbd1 contains a MBD and a TRD, which have analog functions to that of Mecp2 (Ng et al., 2000). In addition, depending on the isoform, Mbd1 contains two or three CXXC zinc finger motifs (Fujita et al., 1999; Jorgensen et al., 2004). The most C-terminal one, referred to as CXXC3, is homolog to zinc fingers found in Dnmt1, CpG binding protein CGBP, histone H3K4 methyltransferase MLL and histone H3K36 deacetylases of the Jumonji family JHDM1A and JHDM1B (Jorgensen et al., 2004; Lee and Skalnik, 2005; Tsukada et al., 2006). While CXXC3 was shown to bind unmethylated CpG dinucleotides in vitro (Birke et al., 2002; Lee and Skalnik, 2002, 2005; Jorgensen et al., 2004), the remaining zinc finger motifs of Mbd1 lack a conserved glutamine residue and the characteristic KFFG motif necessary for binding to DNA (Jorgensen et al., 2004). Accordingly, Mbd1 isoforms containing the first two CXXC domains preferentially bind methylated DNA via their $\mathrm{MBD}$, whereas isoforms comprising a complete set of zinc fingers have the ability to bind both, methylated and unmethylated substrates (Jorgensen et al., 2004; Baubec et al., 2013).

As a transcriptional repressor, Mbd1 was thus shown to inhibit transcription from both, methylated and unmethylated promoters in reporter gene assays (Fujita et al., 1999; Jorgensen et al., 2004). While methylation-dependent silencing is mediated by the MBD and TRD, suppression of non-methylated reporter constructs required the presence of the CXXC3 domain (Jorgensen et al., 2004). Although, a precise association between Mbd1 and HDACs has not been described, transcriptional repression was partially sensitive to trichostatin A (TSA), an HDAC inhibitor (Ng et al., 2000). In most assays, however, Mbd1 behaved as an HDAC-independent repressor (Ng et al., 2000).

Instead, MBD1 has been found associated with histone H3K9 methyltransferases SETDB1 (Sarraf and Stancheva, 2004) and Suv39h1 (Fujita et al., 2003). Association to SETDB1 mediates transcriptional repression throughout the cell cycle (Sarraf and Stancheva, 2004). During S-phase, however, MBD1 was shown to recruit SETDB1 to the large subunit of chromatin assembly factor CAF-1 to form an S-phase specific complex that mediates methylation of $\mathrm{H} 3 \mathrm{~K} 9$ in a post-replicative manner (Sarraf and Stancheva, 2004). Accordingly, H3K9 methylation is lost in the absence of MBD1 and results in activation of specific genes, such as p53BP2 (Sarraf and Stancheva, 2004).

MBD1-mediated transcriptional repression and heterochromatin maintenance was shown to be regulated by SUMOylation (Lyst et al., 2006; Uchimura et al., 2006). In human cells, two E3 SUMO-ligases (PIAS1 and PIAS3) were shown to SUMOylate MBD1 (Lyst et al., 2006). While SUMO1-conjugation blocks the MBD1 and SETDB1 interaction, modification with SUMO2/3 recruits SETDB1 thereby stimulating its repressive function (Uchimura et al., 2006).

Although mice lacking Mbd1 (Table 3) developed normally and appeared healthy throughout life, they were impaired in spatial learning, had decreased neurogenesis and reduced long-term potentiation in the dentate gyrus of the hippocampus

TABLE 3 | Phenotype of initial MBP-deficient mouse models.

\begin{tabular}{|c|c|c|}
\hline Genotype & Phenotype & Reference \\
\hline Mecp2 null & $\begin{array}{l}\text { Rett syndrome-like phenotype. Between } 3 \text { and } 5 \text { weeks: uncoordinated gait, reduced spontaneous movement, hind } \\
\text { limb clasping, irregular breathing, misaligned jaws, uneven wearing of teeth, reduced brain weight, and neuronal cell } \\
\text { size. Between } 6 \text { and } 12 \text { weeks: rapid weight loss and death. }\end{array}$ & $\begin{array}{l}\text { Chen et al., 2001; } \\
\text { Guy et al., } 2001\end{array}$ \\
\hline Mbd1 null & $\begin{array}{l}\text { Viable and fertile. Impaired spatial learning, decreased neurogenesis, reduced long-term potentiation, decreased } \\
\text { genomic stability. }\end{array}$ & Zhao et al., 2003 \\
\hline Mbd2 null & Viable, fertile. Maternal nurturing defects: reduced litter size and weight of pups. & Hendrich et al., 2001 \\
\hline Mbd3 null & Early embryonic lethality & Hendrich et al., 2001 \\
\hline Mbd4 null & Viable and fertile. Increased number of C:G to T:A transitions at CpG sites. & Millar et al., 2002 \\
\hline Kaiso null & Viable and fertile. Reduced tumorigenesis & Prokhortchouk et al., 2006 \\
\hline Np95 null & Early gestational lethality. Developmental arrest shortly after gastrulation. & Sharif et al., 2007 \\
\hline Np97 null & Phenotype not described. & Li et al., 2013 \\
\hline
\end{tabular}


(Zhao et al., 2003). Moreover, Mbd1-deficient neural stem cells differentiated less and had decreased genomic stability (Zhao et al., 2003).

\section{Mbd2}

Mbd2 and Mbd3 are the only known members of the MBD protein family with significant sequence similarity beyond the MBD (Hendrich and Bird, 1998) and, thus, are believed to have arisen from an ancient duplication during evolution of the vertebrate lineage (Hendrich and Tweedie, 2003). Consistent with this, a homolog $\mathrm{Mbd} 2 / 3$ like protein was identified in invertebrates, including Drosophila (Lyko et al., 2000; Marhold et al., 2004). Despite the high degree of sequence similarity, Mbd3 lacks the amino-terminal extension of Mbd2, which contains a repeat consisting of glycine and arginine residues (Hendrich and Bird, 1998). While both, Mbd2 and Mbd 3 contain a C-terminal coiled coil (CC) domain that mediates proteinprotein interactions, $\mathrm{Mbd} 3$ was shown to comprise an additional glutamic acid repeat at its extreme $\mathrm{COOH}$-terminus (Hendrich and Bird, 1998; Gnanapragasam et al., 2011; Becker et al., 2013).

Mbd2 contains two in-frame start codons, which give rise to $\operatorname{Mbd} 2 \mathrm{a}$ and the truncated version $\mathrm{Mbd} 2 \mathrm{~b}$, which lacks the first 140 amino acids (Hendrich and Bird, 1998). In vivo, however, only Mbd2a, but not Mbd2b, has been detected ( $\mathrm{Ng}$ et al., 1999). Inclusion of an alternative third exon gives rise to an additional isoform of $\mathrm{Mbd} 2$, named $\mathrm{Mbd} 2 \mathrm{c}$, which lacks the C-terminal TRD and CC domain due to an early stop codon (Hendrich and Bird, 1998).

Tethering of Mbd2a near a promoter via a GAL4 DNA binding domain was shown to mediate transcriptional repression that is sensitive to TSA ( $\mathrm{Ng}$ et al., 1999). Similarly, Mbd2b enhanced transcriptional repression of methylated reporter constructs in co-transfection assays (Boeke et al., 2000). Different from other MBD family members, the sequence required for TRD partially overlapped with the MBD (Boeke et al., 2000), indicating a strong interrelation of methylation binding and transcriptional silencing. In line with this, the TRD directly interacts with the transcriptional repressor Sin3A (Boeke et al., 2000). Moreover, $\mathrm{Mbd} 2$ co-purified with a large protein complex known as NuRD (nucleosome remodeling and histone deacetylation), which includes chromatin remodeling ATPase Mi-2, as well as HDAC1 and HDAC2 (Ng et al., 1999; Wade et al., 1999; Zhang et al., 1999; Mahajan et al., 2005; Le Guezennec et al., 2006). EMSAs indicated that Mbd2a directs the NuRD complex, which is implicated in transcriptional silencing, to methylated DNA (Zhang et al., 1999). Finally, immunoprecipitation analysis showed that Mbd2 associates with HDAC1 in mammalian cells and is the long sought methyl-CpG binding component of the $400-800 \mathrm{kDa}$ MeCP1 complex (Meehan et al., 1989; Ng et al., 1999).

$\mathrm{Mbd} 2$ was shown to bind $5 \mathrm{mC}$ in a manner similar to the isolated MBD of Mecp2 (Hendrich and Bird, 1998; Wade et al., 1999). Binding of oxidative $5 \mathrm{mC}$ derivatives, however, has not been observed (Hashimoto et al., 2012a; Mellen et al., 2012; Spruijt et al., 2013).

$\mathrm{Mbd} 2 \mathrm{~b}$ has also been reported to have DNA demethylase activity (Bhattacharya et al., 1999), but this finding has been questioned (Ng et al., 1999; Wade et al., 1999).
Mbd2-deficient mice (Table 3) are viable and fertile, but exhibit a maternal nurturing defect resulting in reduced litter size and weight of pups (Hendrich et al., 2001).

\section{Mbd3}

The smallest member of the MBD family, coding for a protein of approximately $30 \mathrm{kDa}$ is Mbd3 (Hendrich and Bird, 1998). It appears in a rich diversity of splice variants and is expressed in ESCs as well as somatic tissues (Hendrich and Bird, 1998; Roloff et al., 2003).

DNA binding properties of Mbd3 seem to vary with species. While mammalian Mbd3 is unable to interact with methylated DNA, its amphibian counterpart binds methylated CpG dinucleotides in vitro and in vivo (Hendrich and Bird, 1998; Wade et al., 1999; Saito and Ishikawa, 2002). Sequence comparison of $5 \mathrm{mC}$ binding competent $\mathrm{MBD}$ domains revealed two highly conserved residues, which are altered in mammalian Mbd3: a largely solvent exposed tyrosine, as well as an aminoterminal lysine or arginine residue (Ohki et al., 1999; Wakefield et al., 1999; Saito and Ishikawa, 2002).

Despite its inability to recognize $5 \mathrm{mC}$, three different $\mathrm{Mbd} 3$ isoforms $(\mathrm{Mbd} 3 \mathrm{a}-\mathrm{c})$ that vary in their amino termini were detected within the NuRD repression complex in embryonic stem cells (Zhang et al., 1999; Kaji et al., 2006). ESCs lacking Mbd3NuRD displayed a severe defect in differentiation that lead to persistent self-renewal even in the absence of leukemia inhibitory factor (Kaji et al., 2006). More recently, depletion of Mbd3 in somatic cells was shown to enhance the reprogramming efficiency of the four Yamanaka factors (Oct4, Sox2, Klf4, and Myc; Luo et al., 2013; Rais et al., 2013). Accordingly, Mbd3 was proposed to play a key role in lineage commitment and pluripotency (Yildirim et al., 2011; Reynolds et al., 2012; Whyte et al., 2012). Contradictory studies using neural and epiblast-derived stem cells, however, indicate a role for Mbd3 in facilitating induction of pluripotency and argue that its function may be context specific (dos Santos et al., 2014).

Binding sites of Mbd3 have been mapped genome-wide in mouse and human cells (Yildirim et al., 2011; Baubec et al., 2013; Gunther et al., 2013; Shimbo et al., 2013). While Yildirim et al. (2011) identified Mbd3 bound to TSS of CpG-rich, hydroxymethylation marked promoters, Baubec et al. (2013) found Mbd3 bound to enhancers independent of CpG density and (hydroxy)methylation status. Further data questioning the interaction of Mbd3 with hydroxymethylated DNA was provided by Spruijt et al. (2013), who did not detect Mbd3 among hydroxymethylation-specific readers.

Although both, Mbd2 and Mbd3 associate with the NuRD complex, the two MBD containing complexes appear to have no functional overlap since knockout of $\mathrm{Mbd} 3$ in mice is embryonic lethal, whereas Mbd2-deficient mice are viable and fertile (Hendrich et al., 2001; Table 3).

\section{Mbd4}

Mbd4, also referred to as MED1 (Bellacosa et al., 1999), is the only known member of the MBD protein family not associated with HDAC activity (Hendrich and Bird, 1998). Instead, several lines of evidence suggest that Mbd4 plays a role in DNA repair 
(Bader et al., 1999; Bellacosa et al., 1999; Hendrich et al., 1999; Riccio et al., 1999; Petronzelli et al., 2000; Millar et al., 2002). In addition to its MBD, Mbd4 contains a C-terminal catalytic domain that is highly homologous to bacterial DNA damage specific endonucleases that exhibit glycosylase activity during BER (Michaels et al., 1990; Hendrich and Bird, 1998). Accordingly, Mbd4 was shown to remove thymine or uracil from mismatched CpG sites through glycosidic bond cleavage. As genomic $\mathrm{G} / \mathrm{T}$ mismatches are the expected product of $5 \mathrm{mCpG}$ deamination, Mbd4 has been designated a methylation specific DNA repair enzyme (Hendrich et al., 1999; Petronzelli et al., 2000; Hashimoto et al., 2012b). Furthermore, Mbd4 has been implicated in DNA demethylation as it was shown in vitro to excise $5 \mathrm{hmU}$, the deamination product of $5 \mathrm{hmC}$ (Hashimoto et al., 2012b).

Knockout and rescue experiments in embryonic stem cells, however, demonstrated that oxidation-dependent reactivation of methylated reporter genes is mediated by the action of thymine DNA glycosylase (TDG), but not by Mbd4 (Muller et al., 2014). Accordingly, deamination of $5 \mathrm{hmC}$ to $5 \mathrm{hmU}$ and subsequent excision by Mbd4 does not play a major role in ESCs (Hashimoto et al., 2012b). A contribution of Mbd4 to Tet-initiated DNA demethylation in NPCs, however, cannot be excluded, since $\mathrm{Mbd} 4$ was shown to bind to $5 \mathrm{hmC}$ at this developmental stage (Spruijt et al., 2013).

Mice lacking Mbd4 are viable and fertile (Millar et al., 2002). However, compared to wild-type mice, Mbd4 knockout lead to a 3.3-fold higher number of C:G to T:A transitions at $\mathrm{CpG}$ sites (Millar et al., 2002). Moreover, Mbd4-/- mice that were made heterozygous for the Min allele of the adenomatous polyposis coli gene (ApcMin), which pre-disposes mice to develop spontaneous intestinal neoplasia (Su et al., 1992), showed markedly reduced survival compared to Mbd $4+/+$ controls. Accordingly, Mbd 4 plays an important role in the repair of $5 \mathrm{mC}$ deamination at $\mathrm{mCpGs}$. The relatively mild phenotype of $\mathrm{Mbd} 4$ knockout mice (Table 3), however, suggests that its absence might be compensated for by other glycosylases, such as TDG.

\section{Kaiso Protein Family}

Members of the Kaiso-like protein family (Figure 6) present a second class of proteins capable of binding specifically to methylated DNA (Filion et al., 2006). In contrast to members of the MBD protein family, Kaiso, Zbtb4, and Zbtb38 contain a conserved BTB/POZ (Bric-a-brac, tramtrack, broad complex/poxvirus and zinc finger) domain involved in proteinprotein interactions and three Kruppel-like C2H2 zinc finger motifs, of which two were found essential for binding to methylated DNA (Filion et al., 2006). Similar to MBD proteins, members of the Kaiso family function as HDAC-dependent transcriptional repressors (Sasai et al., 2005). Several lines of evidence, however, including their variable binding modes, protein partners and expression patterns, suggest that Kaiso-like proteins have different biological functions (Daniel and Reynolds, 1999; Kiefer et al., 2005; Park et al., 2005; Filion et al., 2006).

While Kaiso was shown to require at least two methylated CpG dinucleotides, a single $\mathrm{mCpG}$ proved sufficient for efficient binding of the Zbtb4 and Zbtb38 proteins (Prokhortchouk et al.,
2001; Filion et al., 2006). Besides its ability to bind methylated DNA, in vitro synthesized Kaiso was shown to interact specifically with an unmethylated consensus sequence, the Kaiso binding site (KBS, TCCTGCNA), which can be found at promoters of Wnt target genes (Daniel and Reynolds, 1999; Park et al., 2005). Accordingly, the xWnt11 gene, a target of non-canonical Wnt signaling, was shown to be regulated by Kaiso in Xenopus (Daniel and Reynolds, 1999; Prokhortchouk et al., 2001). Moreover, Kaiso-mediated repression of non-canonical and canonical Wnt targets was repressed by interactions with p120-catenin (Kim et al., 2004), as it competes with DNA for the access to the Kaiso zinc finger domains (Daniel et al., 2002). The ability to bind unmethylated KBS sequences is shared by Zbtb4. Zbtb38, however, was shown to interact with the E-box motif (CACCTG) of the rat tyrosine hydroxylase gene promoter (Kiefer et al., 2005), but failed to bind a labeled KBS probe (Filion et al., 2006). More recently, Kaiso was found to bind $5 \mathrm{hmC}$ in NPCs and Zbtb4 was pulled down with hydroxymethylated DNA from brain tissue (Spruijt et al., 2013). The 5hmC binding domains, as well as the biological function, however, remain to be determined.

Kaiso-like proteins contain a BTB/POZ domain, which facilitates interaction with different sets of co-repressors and mediate transcriptional repression.

Kaiso was shown to recruit the NCoR complex to promoters of target genes to introduce histone hypoacetylation, as well as H3K9 methylation (Yoon et al., 2003). Moreover, Kaiso was identified as component of an alternative MeCP1 complex in NIH3T3 cells (Prokhortchouk et al., 2001). Zbtb38 was found to interact with the co-repressors CtBPs (C-terminal binding proteins), which include HDAC, methyltransferase, and demethylase activities (Sasai et al., 2005; Zocchi and Sassone-Corsi, 2012). Zbtb4 was shown to associate with the Sin3A/HDAC complex to repress expression of $\mathrm{p}_{21}{ }^{\mathrm{CIP} 1}$ in response to stimuli that activate p53 (Weber et al., 2008).

Kaiso-like proteins exhibit diverging expression patterns. While Kaiso is ubiquitously expressed, Zenon, the rat homolog of $Z B T B 38$, is primarily transcribed in brain and neuroendocrine tissues (Kiefer et al., 2005). For Zbtb4, in contrast, high expression levels were identified in brain, lung, kidney, muscle, and heart (Filion et al., 2006).

Kaiso-null mice (Table 3) are viable and fertile, with no detectable changes in gene expression profiles or developmental abnormalities. However, when crossed with tumor-susceptible $\operatorname{Apc}(\mathrm{Min} /+)$ mice, Kaiso-deficient animals showed resistance to intestinal cancer (Prokhortchouk et al., 2006).

\section{SRA Domain Protein Family}

Recent studies implicate that yet another protein fold, the SRA domain could read DNA (hydroxy)methylation marks in vitro and in vivo (Unoki et al., 2004; Johnson et al., 2007; Woo et al., 2007; Frauer et al., 2011a; Spruijt et al., 2013). In mammals, two SRA domain-containing proteins (Figure 7), Np95 (mouse homolog of human ICBP90, gene name UHRF1) and Np97 (mouse homolog of human NIRF, gene name UHRF2), have been characterized (Unoki et al., 2004; Woo et al., 2007; Zhang et al., 2011). While Np95 was first discovered during the generation process of antibodies against murine 

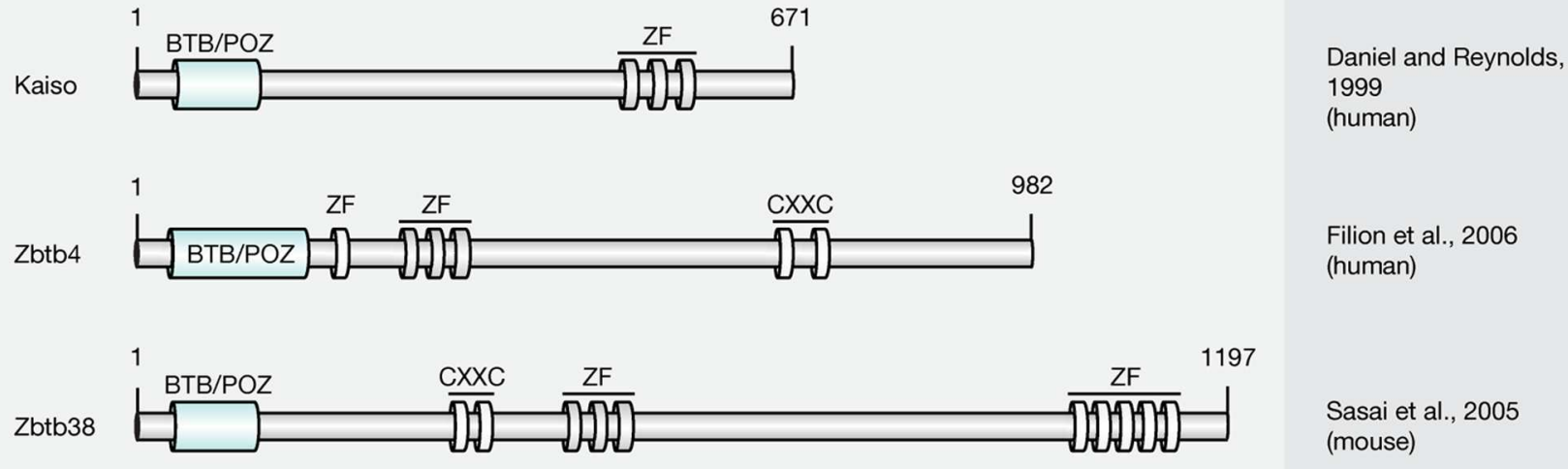

FIGURE 6 | Schematic representation of the Kaiso-like protein family. Shown are domain structures of mouse Kaiso-like proteins and the initial references. Numbers represent amino acid positions. BTB/POZ, broad complex, tramtrack and bric a brac/poxvirus and zinc finger domain; ZF, zinc finger; CXXC, CXXC zinc finger domain.

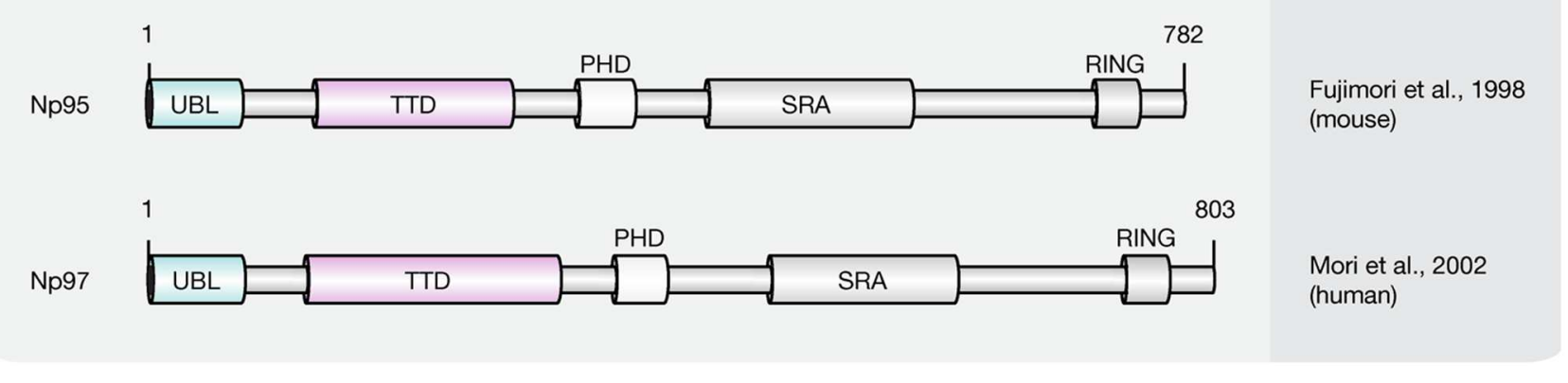

FIGURE 7 | Schematic representation of the SRA domain protein family. Shown are domain structures of mouse SRA domain proteins and the initial references. Numbers represent amino acid positions. UBL, ubiquitin-like domain; TTD, tandem tudor domain; PHD, plant homeodomain; SRA, SET, and RING finger associated domain; RING, really interesting new gene.

thymic lymphoma (Fujimori et al., 1998), NIRF was identified through screenings for PCNP (PEST containing nuclear protein) interaction partners (Mori et al., 2002).

Besides the eponymous SRA domain, ICBP90 contains at least four additional functional motifs (Hashimoto et al., 2009): an N-terminal ubiquitin-like domain (Ubl, or NIRF_N); a tandem Tudor domain (TTD) that binds histone $\mathrm{H} 3$ tails di/trimethylated at lysine 9 (H3K9me2/3; Karagianni et al., 2008; Papait et al., 2008; Rottach et al., 2010); a PHD, which binds (un)modified histones; and a C-terminal RING, which exhibits ubiquitin E3 ligase activity.

ICBP90 and Np95 play a critical role in epigenetic inheritance and maintenance of DNA methylation (Bostick et al., 2007; Sharif et al., 2007). Accordingly, ICBP90/Np95 was shown to colocalize with PCNA during S phase and to interact with Dnmt3a, Dnmt3b and several histone-modifying enzymes like HDAC1, as well as histone methyltransferase G9a (Achour et al., 2009; Kim et al., 2009; Meilinger et al., 2009). Moreover, besides its ability to bind and flip out hemi-methylated DNA, the SRA domain of ICBP90 was shown to target Dnmt1 to replicating pericentric heterochromatin for maintenance methylation (Bostick et al., 2007; Arita et al., 2008; Avvakumov et al., 2008; Hashimoto et al., 2008; Papait et al., 2008). In addition, ICBP90 was shown to bind histone $\mathrm{H} 3 \mathrm{~K} 9 \mathrm{me} 2 / 3$ via its TTD, thus connecting repressive histone marks with DNA methylation (Rottach et al., 2010; Nady et al., 2011; Rothbart et al., 2012). The PHD of ICBP90, on the other hand, was found associated with the N-terminal tail of histone H3 (Papait et al., 2007; Hu et al., 2011; Rajakumara et al., 2011; Wang et al., 2011; Arita et al., 2012; Cheng et al., 2013). More recently, the SRA domain of Np95 was demonstrated to bind $5 \mathrm{hmC}$ and $5 \mathrm{mC}$ containing DNA substrates with similar affinity in vitro (Frauer et al., 2011a). Consistent with this, $\mathrm{Np} 95$ was identified as $5 \mathrm{hmC}$ reader in mESCs and NPCs. In mouse brain tissue, however, association with $5 \mathrm{hmC}$ remained undetected likely due to its low expression levels. Although the structure of NIRF, the second member of the SRA domain protein family, is closely related to ICBP90, both proteins possess significantly different expression patterns. While ICBP90 is mainly expressed in proliferating cells (Fujimori et al., 1998), NIRF protein levels increase during differentiation 
(Pichler et al., 2011). NIRF binds hemi-methylated DNA and $\mathrm{H} 3 \mathrm{~K} 9 \mathrm{me} 2 / 3$ containing heterochromatin marks in a cooperative manner, whereby localization and in vivo binding dynamics of NIRF, were shown to require an intact TTD and depend on H3K9me3 but not on DNA methylation (Pichler et al., 2011). While Np95 was shown to bind $5 \mathrm{hmC}$ in mESCs and NPCs, the interaction of $\mathrm{Np} 97$ and $5 \mathrm{hmC}$ was specific for NPCs. Furthermore, Np97 exhibited higher binding affinity for $5 \mathrm{hmC}$ than for 5mC in NPCs (Spruijt et al., 2013). Finally, Np97 was proposed to promote repetitive oxidation of $5 \mathrm{mC}$ by Tet proteins, since the levels of the oxidative cytosine derivatives $5 \mathrm{hmC}, 5 \mathrm{fC}$ and $5 \mathrm{caC}$ were increased upon coexpression of Np97 and Tet1 in HEK293T cells (Spruijt et al., 2013). Consequently, Spruijt et al. (2013), hypothesized that flipping of the modified base, as previously described for Np95, may enhance the accessibility of Tet enzymes to the hydroxymethylated base, whereby further oxidation is promoted.

Furthermore, ectopic Np97 was unable to rescue DNA methylation defects observed in Np95-/- ESCs. Neither DNA methylation levels, nor pericentric heterochromatin localization of Dnmt1 in S-phase could be restored upon overexpression of Np97 arguing for functional differences between both proteins (Pichler et al., 2011). NIRF was found to interact with cell cycle proteins including cyclins, cyclin-dependent kinases (CDKs), retinoblastoma protein (pRB), p53, PCNA, HDAC1, DNMTs, and G9a (Mori et al., 2012). It was shown to ubiquitinate cyclins D1 and E1, and to induce G1 arrest. Accordingly, NIRF was proposed to link the cell cycle regulatory network with the epigenetic landscape (Mori et al., 2012).

While knockout of Np95 leads to developmental arrest shortly after gastrulation and early gestational lethality (Sharif et al., 2007), the phenotype of Np97 null mice has not been analyzed (Li et al., 2013; Table 3).

\section{ROLE OF 5mC WRITERS, READERS, AND MODIFIERS IN DISEASE}

Mutations in proteins involved in writing, reading, and modifying the epigenetic landscape have been implicated in various severe human disorders. Due to their high sequence (Table 4) and functional similarity (Kumar et al., 1994; Hendrich and Bird, 1998; Mori et al., 2002; Filion et al., 2006; Bostick et al., 2007; Ito et al., 2010; Qin et al., 2011), we, hereafter, summarize the state-of-the-art regarding the role of the human orthologs of the aforementioned mouse Dnmts, Tets, and MBPs in human diseases.

\section{DNMT Proteins in Disease}

Since Dnmt1 knockout is embryonic lethal in mice, it is unlikely to expect a human disease linked to a DNMT1 catalytic domain mutation. But mutations in the regulatory domain of DNMT1 were found (Table 5). Mutations in the TS domain of DNMT1 cause neurodegeneration like hereditary sensory autonomic neuropathy with dementia and hearing loss (HSAN1E; Klein et al., 2011) and autosomal
TABLE 4 | Comparison of human proteins and their mouse orthologs.

\begin{tabular}{lll}
\hline Mouse protein & Human protein & Amino acid similarity (\%) \\
\hline Dnmt1 (1620 aa) & DNMT1 (1632 aa) & 76 \\
Dnmt2 (415 aa) & DNMT2 (391 aa) & 96 \\
Dnmt3a (908 aa) & DNMT3A (912 aa) & 80 \\
Dnmt3b (860 aa) & DNMT3B (853 aa) & 56 \\
Dnmt3 (421 aa) & DNMT3L (387 aa) & 50 \\
Tet1 (2039 aa) & TET1 (2136 aa) & 55 \\
Tet2 (1912 aa) & TET2 (2002 aa) & 89 \\
Tet3 (1803 aa) & TET3 (1795 aa) & 94 \\
Mecp2 (501 aa) & MECP2 (498 aa) & 68 \\
Mbd1 (636 aa) & MBD1 (605 aa) & 94 \\
Mbd2 (414 aa) & MBD2 (411 aa) & 58 \\
Mbd3 (285 aa) & MBD3 (291 aa) & 84 \\
Mbd4 (554 aa) & MBD4 (580 aa) & 85 \\
Kaiso (671 aa) & KAISO (672 aa) & 81 \\
Zbtb4 (982 aa) & ZBTB4 (1013 aa) & 72 \\
Zbtb38 (1197 aa) & ZBTB38 (1195 aa) & 90 \\
Np95 (782 aa) & ICBP90 (806 aa) & \\
Np97 (803 aa) & NIRF (802 aa) & aa \\
\hline
\end{tabular}

dominant cerebellar ataxia, deafness and narcolepsy (ADCADN; Winkelmann et al., 2012). Mutations of Y495C, Y495H, D490E-P491Y (Klein et al., 2011, 2013) in exon 20 cause HSAN1E. Those mutations caused premature degradation of mutant proteins, reduced methyltransferase activity and impaired heterochromatin binding during G2 phase leading to global hypomethylation and site-specific hypermethylation (Klein et al., 2011). ADCA-DN is a polymorphic disorder first described in 1995 in a Swedish pedigree. Unlike mutations in HSAN1E located in exon 20, mutations in ADCA-DN including A570V, G605A, and V606F were found in exon 21 of the DNMT1 gene.

Mutations in DNMT3A were found in de novo AML and are associated with poor survival (Table 5; Ley et al., 2011). The most frequent mutation occurred in amino acid R882, however, frameshift, nonsense and splice site mutations were also reported (Ley et al., 2011). Mutations of DNMT3A are not only observed in AML patients, but also in MDS. Similar to mutations leading to AML, amino acid R882 located in the methyltransferase domain of DNMT3A is the most common mutation site (Walter et al., 2011). Unlike in AML and MDS, most mutations in overgrowth syndrome do not directly affect the catalytic activity of DNMT3A, but interfere with domain-domain interactions and histone binding, which further affect the activity of DNMT3A (Tatton-Brown et al., 2014).

ICF syndrome (immunodeficiency, chromosomal instability, and facial anomalies), a human genetic disorder is caused by DNMT3B mutations (Table 5; Hansen et al., 1999; Xu et al., 1999). Several mutations were identified and most mutations are located in the catalytic domain of DNMT3B and directly affect the activity of DNMT3B (Xu et al., 1999). However, mutations, which do not directly affect its catalytic activity were also observed in ICF syndrome. Two mutations, A766P and 
TABLE 5 | Summary of disease-related DNMT and TET mutations.

\begin{tabular}{|c|c|c|c|}
\hline Protein & Disease & Alteration & Reference \\
\hline DNMT1 & $\begin{array}{l}\text { Hereditary sensory autonomic neuropathy with dementia } \\
\text { and hearing loss (HSAN1E) }\end{array}$ & Y495C, Y495H, D490E-P491Y & Klein et al., 2011, 2013 \\
\hline DNMT1 & $\begin{array}{l}\text { Autosomal dominant cerebellar ataxia, deafness and } \\
\text { narcolepsy (ADCA-DN) }\end{array}$ & A570V, G605A, and V606F & Winkelmann et al., 2012 \\
\hline DNMT3A & $\begin{array}{l}\text { Acute myeloid leukemia (AML) myelodysplastic syndrome } \\
\text { (MDS) }\end{array}$ & R882 and frameshift, nonsense and splice site mutations & $\begin{array}{l}\text { Ley et al., 2011; } \\
\text { Walter et al., } 2011\end{array}$ \\
\hline DNMT3A & Overgrowth syndrome & $\begin{array}{l}\text { Mutations interfere with domain-domain interactions and } \\
\text { histone binding }\end{array}$ & Tatton-Brown et al., 2014 \\
\hline DNMT3B & $\begin{array}{l}\text { Immunodeficiency, centromeric region instability, facial } \\
\text { anomalies syndrome (ICF) syndrome }\end{array}$ & Mutations in catalytic domain & $\begin{array}{l}\text { Hansen et al., 1999; } \\
\text { Xu et al., } 1999\end{array}$ \\
\hline TET1 & AML & $\begin{array}{l}\text { Ten-eleven translocation that gives rise to a MLL-TET1 } \\
\text { fusion }\end{array}$ & Lorsbach et al., 2003 \\
\hline TET2 & AML, MDS, and myeloproliferative neoplasms & Mutations mostly in catalytic domain & Abdel-Wahab et al., 2009 \\
\hline
\end{tabular}

R840Q displayed similar methylation activity than the wild-type enzyme but lost the ability to interact with DNMT3L, which further leads to loss of activity in vivo (Xie et al., 2006). Direct or indirect loss of DNMT3B activity consequently decreased satellite DNA methylation in ICF syndrome patients, indicating that DNMT3B is involved in maintaining genome stability.

$5 \mathrm{mC}$, the product of DNMTs is related to tumorigenesis. It was shown that the genome of cancer cells is globally hypomethylated relative to their normal counterparts. Usually, hypomethylation leads to gene activation. In cancer cells, the activation of genes is caused by hypomethylation of nearby CGIs, which are silenced in somatic tissues by DNA methylation (Strichman-almashanu et al., 2002). Satellite sequences and repetitive sequences such as LINE1, SINE, IAP, and Alu elements are silenced mainly by DNA methylation in normal cells. However, in tumor cells, hypomethylation of L1 promoter was detected and the activation of L1 might promote chromosomal rearrangements and genome instability (Suter et al., 2004). Although the cancer genome is hypomethylated, several studies showed that Dnmts are upregulated in cancer cells (Ahluwalia et al., 2001; Lin et al., 2007; Roll et al., 2008), suggesting that demethylation enzymes might be additionally involved in loss of DNA methylation in cancer.

\section{TET Proteins in Disease}

$M L L$ gene is located in $11 \mathrm{q} 23$ and is the most frequent cytogenetic finding in AML. In AML, MLL is translocated to chromosome 10 as a fusion with the TET1 gene. The MLL-TET1 fusion protein contains the AT hooks, subnuclear localization domains, and the CXXC domain of MLL and the C-terminus of TET1 (Table 5; Lorsbach et al., 2003). The function of MLL-TET1 fusion protein is still unknown, but it was showed that TET1 is involved in MLL-rearranged leukemia. TET1 is a direct target of the MLL-fusion protein and is significantly upregulated in MLLrearranged leukemia, leading to a global increase $5 \mathrm{hmC}$, thus playing an oncogenic role (Huang et al., 2013).

In myeloproliferative neoplasms, mutations of TET2 but not TET1 and TET3 were observed (Table 5; Abdel-Wahab et al., 2009). Mutations of TET2 were also observed in AML with varied frequency and most of them occurred in the catalytic domain of
TET2. In AML, TET2 mutations correlate with genomic 5hmC level (Konstandin et al., 2011). TET2 is one of the most frequently mutated genes in MDS. Mutations of TET2 were detected in most of the bone marrow cells in MDS and these mutations contribute to the malignant transformation of bone marrow cells (Langemeijer et al., 2009), which consequently displayed uniformly low levels of $5 \mathrm{hmC}$ in genomic DNA compared to bone marrow samples from healthy controls (Ko et al., 2010).

Besides the hematopoietic malignancies, $5 \mathrm{hmC}$ levels are also changed in solid tumors. $5 \mathrm{hmC}$ level were profoundly reduced in glioma, colon cancer, breast cancer, and melanoma compared to normal tissues (Haffner et al., 2011; Jin et al., 2011; Li and Liu, 2011; Xu W. et al., 2011; Kraus et al., 2012).

Unlike in cancer, in the hippocampus/parahippocampal gyrus (HPG) of preclinical and later-stage Alzheimer's disease patients, significantly increased levels of TET1, $5 \mathrm{mC}$, and $5 \mathrm{hmC}$ were observed. In contrast, levels of $5 \mathrm{fC}$ and $5 \mathrm{caC}$ were significantly decreased in the HPG of these patients (Bradley-Whitman and Lovell, 2013). This indicates that DNA methylation might play an important role in memory-related disease.

\section{MBPs in Disease}

As readers and translators of epigenetic information, alterations in MBP sequences affect the precisely coordinated link between DNA methylation, histone modification and higher order chromatin structure.

Mutations in the $\mathrm{X}$-linked $M E C P 2$ gene give rise to RTT (Table 6), a late onset (6-18 months post-birth) debilitating neurological disease that affects 1 in 10,000-15,000 female live births (Hagberg et al., 1983; Amir et al., 1999). After a period of normal development (6-18 months), RTT patients usually lose speech and acquired motor skills (Hagberg et al., 1983). They are afflicted with seizures, autism, loss of motor coordination, abnormal breathing and develop stereotypical, repetitive hand movements (Hagberg et al., 1983). After the initial regression, however, conditions often stabilize and allow viability until adulthood (Rett, 1966; Hagberg et al., 1983).

Although the first patients were described in 1966 by Andreas Rett (Rett, 1966), more than 30 years passed before mutations within the MECP2 gene located in Xq28 were identified as 
TABLE 6 | Summary of disease-related MBP alterations.

\begin{tabular}{|c|c|c|c|}
\hline Protein & Disease & Alteration & Reference \\
\hline MECP2 & Rett syndrome & $\begin{array}{l}\text { Causal MECP2 mutations of Rett syndrome are } \\
\text { summarized in: http://mecp2.chw.edu.au/mecp2/index.php }\end{array}$ & Amir et al., 1999 \\
\hline MBD1 & Prostate cancer & Upregulated & Patra et al., 2003 \\
\hline MBD2 & Breast cancer & Upregulated & Billard et al., 2002 \\
\hline MBD3 & Glioblastoma & Upregulated & Schlegel et al., 2002 \\
\hline MBD4 & $\begin{array}{l}\text { Colorectal cancer } \\
\text { Endometrial cancer } \\
\text { Pancreas cancer }\end{array}$ & $\begin{array}{l}\text { Frameshift mutation } \\
\text { Frameshift mutation } \\
\text { Frameshift mutation }\end{array}$ & Riccio et al., 1999 \\
\hline KAISO & Colorectal cancer & Upregulated & Lopes et al., 2008 \\
\hline ZBTB4 & Neuroblastoma & Downregulated & Weber et al., 2008 \\
\hline ICBP90 & Non-small-cell lung cancer & Upregulated & Daskalos et al., 2011 \\
\hline NIRF & Lung cancer & Upregulated & He et al., 2009 \\
\hline
\end{tabular}

the cause of the neurological disorder (Amir et al., 1999). The most frequent mutations observed in patients suffering from RTT are missense mutations that cluster within the MBD (aa 78-162), as well as nonsense mutations primarily found within the TRD (aa 207-310; Christodoulou et al., 2003). In Xenopus, missense mutations R106W, R133C, F155S, and T158M were shown to reduce the binding ability of Mecp2 to methylated DNA (Ballestar et al., 2000). Studies in mouse cells showed that the majority of MBD-related missense mutations affected the heterochromatin binding and/or clustering ability of Mecp2 (Agarwal et al., 2011). By artificially targeting chromatin binding deficient Rett mutants (R111G, R133L, and F155S) to constitutive heterochromatic regions, however, Casas-Delucchi et al. (2012) revealed that some of these mutations exclusively affect the chromatin binding but not linking ability. Mutations within the TRD have been shown to influence protein-protein interactions. In knock-in mice bearing the common RTT mutation R306C, neuronal activity fails to induce T308 phosphorylation, a PTM required to suppress the interaction of Mecp2 with the corepressor complex NCoR. Accordingly, R306C mutations result in persistent association of both proteins leading to decreased induction of a subset of activity-related genes (Ebert et al., 2013; Lyst et al., 2013). In addition to missense and nonsense mutations, reading frame shifts and C-term deletions were shown to give rise to RTT. Mice bearing a truncating mutation similar to those found in RTT patients showed normally localized Mecp2 proteins (Shahbazian et al., 2002). Histone H3, however, was hyperacetylated indicating abnormal chromatin architecture and misregulated gene expression (Shahbazian et al., 2002). Moreover, Muotri et al. (2010) identified increased susceptibility for L1 transposition and genome instability in RTT patients with truncating mutations.

In addition to RTT, Mecp2 was implicated in other neurological diseases, including Hirschsprung's disease, autism spectrum disorder, schizophrenia, Prader-Willi, and Angelman syndromes (Carney et al., 2003; Shibayama et al., 2004; Nagarajan et al., 2006; Loat et al., 2008; Ramocki et al., 2009; Zhou et al., 2013).

More recently MBP have been associated with several types of human cancers (Table 6). While Mecp2 was overexpressed in estrogen receptor positive human breast cancer (Muller et al., 2003), MBD1 mRNA and protein levels were increased in

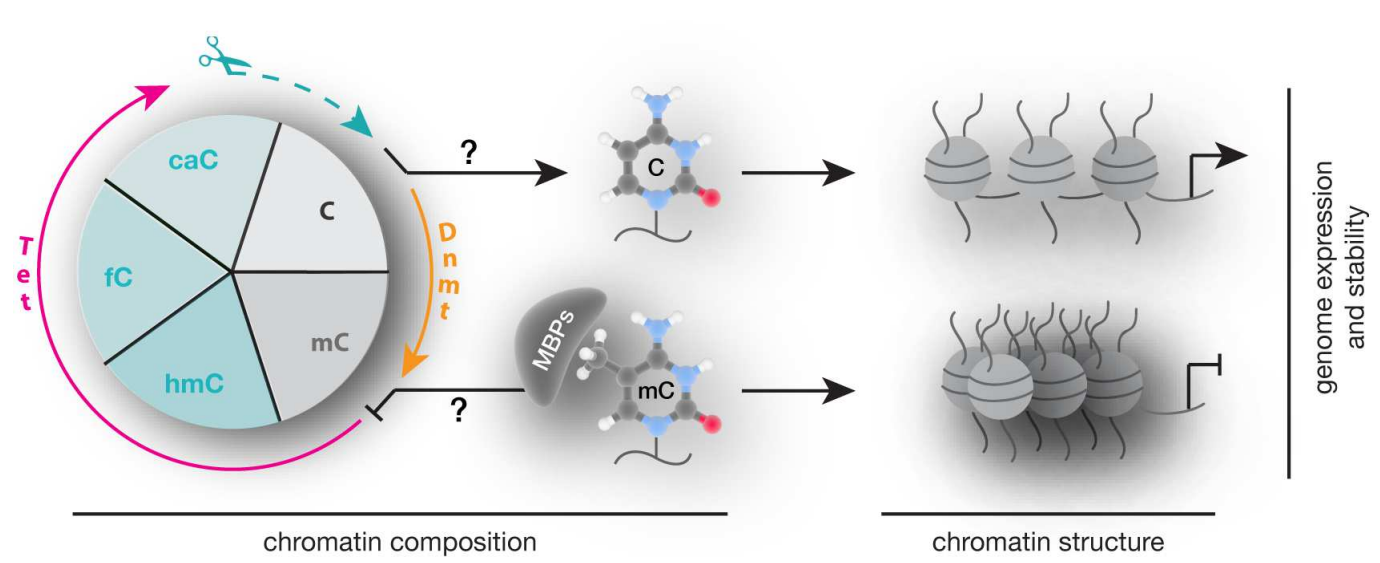

FIGURE 8 | Writing, reading, and translating DNA modifications. Graphical summary of how DNA modification writers, readers, and translators can impact on chromatin composition, structure (nucleosomes are represented as balls, DNA as line) as well as genome expression (arrow represents active promoters) and stability. 
prostate cancer (Patra et al., 2003). Accordingly, Patra et al. (2003) proposed MBD1 as the major cause of hypermethylated chromatin regions in prostate cancer through the recruitment of HDAC1/2 and subsequent histone deacetylation. MBD2 mRNA level were shown to be significantly elevated in benign tumors of the breast and correlated with tumor size of invasive ductal carcinomas, the most common type of breast cancer (Billard et al., 2002). Accordingly, upregulation of MBD2 was proposed to be associated with breast cell proliferation (Billard et al., 2002). Increased expression of MBD3 and MBD4 were associated with malignant glioma of the brain, and the grade of malignancy correlated with MBD3/4 expression level (Schlegel et al., 2002). Furthermore, frameshift mutations of MBD4 have been identified in colorectal, endometrial and pancreatic cancer with microsatellite instability (Riccio et al., 1999). MBD4 mutations consisted of 1- to 2-bp deletions or 1-bp insertions that caused frameshifts and premature stop codons. The resultant truncated MBD4 proteins were predicted to be non-functional, as they lack the C-terminal catalytic domain, whereby genomic instability was proposed to steadily increase (Riccio et al., 1999). As a regulator of target genes of the canonical and non-canonical Wnt pathway, Kaiso was shown to mediate silencing of tumor suppressor genes CDKN2A and HIC1 in Wnt-driven human colon cancer cell lines (Lopes et al., 2008). Kaiso depletion induced expression of tumor suppressor genes without altering DNA methylation levels (Lopes et al., 2008). As a result, colon cancer cells became susceptible to cell cycle arrest and cell death induced by chemotherapy (Lopes et al., 2008). Accordingly, Lopes et al. (2008) suggested Kaiso as a methylation-dependent oncogene that represses hypermethylated tumor suppressor genes. ZBTB4 expression was shown to be downregulated in advanced stages of human neuroblastoma and multiple human solid tumors (Weber et al., 2008). As a repressor of the $P 21^{C I P 1}$ gene, an inhibitor of the Cdk2 kinase, ZBTB4 usually blocks cell cycle arrest in response to p53 activation (Weber et al., 2008). Consequently, loss of ZBTB4 inhibits apoptosis and favors long-term survival of affected cells (Weber et al., 2008). In tumors, where many promoter-associated CGIs are hypermethylated, maintenance of methylation plays a major role. Accordingly, elevated levels of ICBP90 were shown to control cell cycle through maintenance of promoter methylation at CDK2A and RASSF1 in non-small-cell lung cancer (Daskalos

\section{REFERENCES}

Aapola, U., Kawasaki, K., Scott, H. S., Ollila, J., Vihinen, M., Heino, M., et al. (2000). Isolation and initial characterization of a novel zinc finger gene, DNMT3L, on $21 \mathrm{q} 22.3$, related to the cytosine-5-methyltransferase 3 gene family. Genomics 65 , 293-298. doi: 10.1006/geno.2000.6168

Abdel-Wahab, O., Mullally, A., Hedvat, C., Garcia-Manero, G., Patel, J., Wadleigh, M., et al. (2009). Genetic characterization of TET1, TET2, and TET3 alterations in myeloid malignancies. Blood 114, 144-147. doi: 10.1182/blood2009-03-210039

Achour, M., Fuhrmann, G., Alhosin, M., Ronde, P., Chataigneau, T., Mousli, M., et al. (2009). UHRF1 recruits the histone acetyltransferase Tip60 and controls its expression and activity. Biochem. Biophys. Res. Commun. 390, 523-528. doi: 10.1016/j.bbrc.2009.09.131

Adams, V. H., McBryant, S. J., Wade, P. A., Woodcock, C. L., and Hansen, J. C. (2007). Intrinsic disorder and autonomous domain function in the et al., 2011). Finally, decreased expression of let-7a miRNA in lung cancer was shown to result in elevated NIRF and reduced $\mathrm{P} 21^{\mathrm{CIP} 1}$ protein level, thereby most likely contributing to lung carcinogenesis (He et al., 2009).

\section{CONCLUDING REMARKS}

In summary, alterations in $5 \mathrm{mC}$ writers, readers, and modifiers that affect their level, PTMs, ability to bind and/or modify DNA and protein interactions are each and all potential mechanisms contributing to altered chromatin composition and structure as well as genome activity and stability (Figure 8) and contribute to an overwhelming variety of human diseases. Despite intensive research, genotype-phenotype connections have been generally difficult to establish and subsequent studies are urgently needed to elucidate potential strategies for diagnostic and therapeutic applications.

\section{AUTHOR CONTRIBUTIONS}

All authors listed, have made substantial, direct and intellectual contribution to the work, and approved it for publication.

\section{FUNDING}

Our research has been supported by grants of the German Research Foundation (DFG), the Volkswagen Foundation, and the German Ministry for Education and Research (BMBF). PZ was funded by a fellowship of the Chinese Scholarship Council.

\section{ACKNOWLEDGMENTS}

We apologize to the colleagues whose work was not cited due to space constraints. We thank all the past and present members of our laboratory for their many contributions along the years. Last but not least, we thank our collaborators over the years, which have made our work so much more enjoyable.

multifunctional nuclear protein, MeCP2. J. Biol. Chem. 282, 15057-15064. doi: 10.1074/jbc.M700855200

Agarwal, N., Becker, A., Jost, K. L., Haase, S., Thakur, B. K., Brero, A., et al. (2011). MeCP2 Rett mutations affect large scale chromatin organization. Hum. Mol. Genet. 20, 4187-4195. doi: 10.1093/hmg/ddr346

Ahluwalia, A., Hurteau, J. A., Bigsby, R. M., and Nephew, K. P. (2001). DNA methylation in ovarian cancer. II. Expression of DNA methyltransferases in ovarian cancer cell lines and normal ovarian epithelial cells. Gynecol. Oncol. 82, 299-304. doi: 10.1006/gyno.2001.6284

Akbarian, S., Chen, R. Z., Gribnau, J., Rasmussen, T. P., Fong, H., Jaenisch, R., et al. (2001). Expression pattern of the Rett syndrome gene MeCP2 in primate prefrontal cortex. Neurobiol. Dis. 8, 784-791. doi: 10.1006/nbdi.2001.0420

Amir, R. E., Van den Veyver, I. B., Wan, M., Tran, C. Q., Francke, U., and Zoghbi, H. Y. (1999). Rett syndrome is caused by mutations in X-linked MECP2, encoding methyl-CpG-binding protein 2. Nat. Genet. 23, 185-188. doi: $10.1038 / 13810$ 
Amouroux, R., Nashun, B., Shirane, K., Nakagawa, S., Hill, P. W. S., D’Souza, Z., et al. (2016). De novo DNA methylation drives $5 \mathrm{hmC}$ accumulation in mouse zygotes. Nat. Cell Biol. 18, 225-233. doi: 10.1038/ncb3296

Aoki, A., Suetake, I., Miyagawa, J., Fujio, T., Chijiwa, T., Sasaki, H., et al. (2001). Enzymatic properties of de novo-type mouse DNA (cytosine-5) methyltransferases. Nucleic Acids Res. 29, 3506-3512. doi: 10.1093/nar/29.17.3506

Arita, K., Ariyoshi, M., Tochio, H., Nakamura, Y., and Shirakawa, M. (2008). Recognition of hemi-methylated DNA by the SRA protein UHRF1 by a baseflipping mechanism. Nature 455, 818-821. doi: 10.1038/nature07249

Arita, K., Isogai, S., Oda, T., Unoki, M., Sugita, K., Sekiyama, N., et al. (2012). Recognition of modification status on a histone $\mathrm{H} 3$ tail by linked histone reader modules of the epigenetic regulator UHRF1. Proc. Natl. Acad. Sci. U.S.A. 109, 12950-12955. doi: 10.1073/pnas.1203701109

Avvakumov, G. V., Walker, J. R., Xue, S., Li, Y., Duan, S., Bronner, C., et al. (2008). Structural basis for recognition of hemi-methylated DNA by the SRA domain of human UHRF1. Nature 455, 822-825. doi: 10.1038/nature07273

Bachman, M., Uribe-Lewis, S., Yang, X., Williams, M., Murrell, A., and Balasubramanian, S. (2014). 5-Hydroxymethylcytosine is a predominantly stable DNA modification. Nat. Chem. 6, 1049-1055. doi: 10.1038/nchem. 2064

Bader, S., Walker, M., Hendrich, B., Bird, A., Bird, C., Hooper, M., et al. (1999). Somatic frameshift mutations in the MBD4 gene of sporadic colon cancers with mismatch repair deficiency. Oncogene 18, 8044-8047. doi: 10.1038/sj.onc. 1203229

Ballestar, E., Yusufzai, T. M., and Wolffe, A. P. (2000). Effects of Rett syndrome mutations of the methyl-CpG binding domain of the transcriptional repressor $\mathrm{MeCP} 2$ on selectivity for association with methylated DNA. Biochemistry 39, 7100-7106. doi: 10.1021/bi0001271

Baubec, T., Ivanek, R., Lienert, F., and Schubeler, D. (2013). Methylationdependent and -independent genomic targeting principles of the MBD protein family. Cell 153, 480-492. doi: 10.1016/j.cell.2013.03.011

Bauer, C., Göbel, K., Nagaraj, N., Colantuoni, C., Wang, M., Müller, U., et al. (2015). Phosphorylation of TET proteins is regulated via O-GlcNAcylation by the O-Linked N-Acetylglucosamine transferase (OGT). J. Biol. Chem. 290, 4801-4812. doi: 10.1074/jbc.M114.605881

Baymaz, H. I., Fournier, A., Laget, S., Ji, Z., Jansen, P. W., Smits, A. H., et al. (2014). MBD5 and MBD6 interact with the human PR-DUB complex through their methyl-CpG-binding domain. Proteomics 14, 2179-2189. doi: $10.1002 /$ pmic. 201400013

Becker, A., Allmann, L., Hofstatter, M., Casa, V., Weber, P., Lehmkuhl, A., et al. (2013). Direct homo- and hetero-interactions of MeCP2 and MBD2. PLoS ONE 8:e53730. doi: 10.1371/journal.pone.0053730

Becker, A., Zhang, P., Allmann, L., Meilinger, D., Bertulat, B., Eck, D., et al. (2016). Poly(ADP-ribosyl)ation of Methyl CpG Binding Domain Protein 2 regulates chromatin structure. J. Biol. Chem. 291, 4873-4881. doi: 10.1074/jbc.M115.698357

Bednar, J., Horowitz, R. A., Grigoryev, S. A., Carruthers, L. M., Hansen, J. C., Koster, A. J., et al. (1998). Nucleosomes, linker DNA, and linker histone form a unique structural motif that directs the higher-order folding and compaction of chromatin. Proc. Natl. Acad. Sci. U.S.A. 95, 14173-14178. doi: 10.1073/pnas.95.24.14173

Bellacosa, A., Cicchillitti, L., Schepis, F., Riccio, A., Yeung, A. T., Matsumoto, Y., et al. (1999). MED1, a novel human methyl-CpG-binding endonuclease, interacts with DNA mismatch repair protein MLH1. Proc. Natl. Acad. Sci. U.S.A. 96, 3969-3974. doi: 10.1073/pnas.96.7.3969

Bestor, T., Laudano, A., Mattaliano, R., and Ingram, V. (1988). Cloning and sequencing of a cDNA encoding DNA methyltransferase of mouse cells. J. Mol. Biol. 203, 971-983. doi: 10.1016/0022-2836(88)90122-2

Bhattacharya, S. K., Ramchandani, S., Cervoni, N., and Szyf, M. (1999). A mammalian protein with specific demethylase activity for mCpG DNA. Nature 397, 579-583. doi: 10.1038/17533

Bian, C., and Yu, X. (2014). PGC7 suppresses TET3 for protecting DNA methylation. Nucleic Acids Res. 42, 2893-2905. doi: 10.1093/nar/gkt1261

Billard, L. M., Magdinier, F., Lenoir, G. M., Frappart, L., and Dante, R. (2002). $\mathrm{MeCP} 2$ and MBD2 expression during normal and pathological growth of the human mammary gland. Oncogene 21, 2704-2712. doi: 10.1038/sj/onc/1205357
Birke, M., Schreiner, S., Garcia-Cuellar, M. P., Mahr, K., Titgemeyer, F., and Slany, R. K. (2002). The MT domain of the proto-oncoprotein MLL binds to CpGcontaining DNA and discriminates against methylation. Nucleic Acids Res. 30, 958-965. doi: 10.1093/nar/30.4.958

Blaschke, K., Ebata, K. T., Karimi, M. M., Zepeda-Martinez, J. A., Goyal, P., Mahapatra, S., et al. (2013). Vitamin C induces Tet-dependent DNA demethylation and a blastocyst-like state in ES cells. Nature 500, 222-226. doi: 10.1038 /nature12362

Boeke, J., Ammerpohl, O., Kegel, S., Moehren, U., and Renkawitz, R. (2000). The minimal repression domain of MBD2b overlaps with the methyl-CpG-binding domain and binds directly to Sin3A. J. Biol. Chem. 275, 34963-34967. doi: 10.1074/jbc.M005929200

Bostick, M., Kim, J. K., Esteve, P. O., Clark, A., Pradhan, S., and Jacobsen, S. E. (2007). UHRF1 plays a role in maintaining DNA methylation in mammalian cells. Science 317, 1760-1764. doi: 10.1126/science.1147939

Bourc'his, D., Xu, G. L., Lin, C. S., Bollman, B., and Bestor, T. H. (2001). Dnmt3L and the establishment of maternal genomic imprints. Science (New York) 294, 2536-2539. doi: 10.1126/science.1065848

Bradley-Whitman, M. A., and Lovell, M. A. (2013). Epigenetic changes in the progression of Alzheimer's disease. Mech. Ageing Dev. 134, 486-495. doi: 10.1016/j.mad.2013.08.005

Brero, A., Easwaran, H. P., Nowak, D., Grunewald, I., Cremer, T., Leonhardt, H., et al. (2005). Methyl CpG-binding proteins induce large-scale chromatin reorganization during terminal differentiation. J. Cell Biol. 169, 733-743. doi: $10.1083 /$ jcb. 20002062

Cardoso, M. C., and Leonhardt, H. (1999). DNA methyltransferase is actively retained in the cytoplasm during early development. J. Cell Biol. 147, 25-32. doi: $10.1083 /$ jcb.147.1.25

Carney, R. M., Wolpert, C. M., Ravan, S. A., Shahbazian, M., Ashley-Koch, A., Cuccaro, M. L., et al. (2003). Identification of MeCP2 mutations in a series of females with autistic disorder. Pediatr. Neurol. 28, 205-211. doi: 10.1016/S08878994(02)00624-0

Casas-Delucchi, C. S., Becker, A., Bolius, J. J., and Cardoso, M. C. (2012). Targeted manipulation of heterochromatin rescues MeCP2 Rett mutants and re-establishes higher order chromatin organization. Nucleic Acids Res. 40, e176. doi: 10.1093/nar/gks784

Chahrour, M., Jung, S. Y., Shaw, C., Zhou, X., Wong, S. T., Qin, J., et al. (2008). $\mathrm{MeCP}$, a key contributor to neurological disease, activates and represses transcription. Science 320, 1224-1229. doi: 10.1126/science.1153252

Chen, Q., Chen, Y., Bian, C., Fujiki, R., and Yu, X. (2013). TET2 promotes histone O-GlcNAcylation during gene transcription. Nature 493, 561-564. doi: 10.1038/nature11742

Chen, R. Z., Akbarian, S., Tudor, M., and Jaenisch, R. (2001). Deficiency of methylCpG binding protein-2 in CNS neurons results in a Rett-like phenotype in mice. Nat. Genet. 27, 327-331. doi: 10.1038/85906

Chen, T., Ueda, Y., Dodge, J. E., Wang, Z., and Li, E. (2003). Establishment and maintenance of genomic methylation patterns in mouse embryonic stem cells by Dnmt3a and Dnmt3b. Mol. Cell. Biol. 23, 5594-5605. doi: 10.1128/MCB.23.16.5594

Chen, T., Ueda, Y., Xie, S., and Li, E. (2002). A novel Dnmt3a isoform produced from an alternative promoter localizes to euchromatin and its expression correlates with active de novo methylation. J. Biol. Chem. 277, 38746-38754. doi: 10.1074/jbc.M205312200

Cheng, J., Huang, M., Zhu, Y., Xin, Y. J., Zhao, Y. K., Huang, J., et al. (2014). SUMOylation of MeCP2 is essential for transcriptional repression and hippocampal synapse development. J. Neurochem. 128, 798-806. doi: 10.1111/jnc.12523

Cheng, J., Yang, Y., Fang, J., Xiao, J., Zhu, T., Chen, F., et al. (2013). Structural insight into coordinated recognition of trimethylated histone $\mathrm{H} 3$ lysine 9 (H3K9me3) by the plant homeodomain (PHD) and tandem tudor domain (TTD) of UHRF1 (ubiquitin-like, containing PHD and RING finger domains, 1) protein. J. Biol. Chem. 288, 1329-1339. doi: 10.1074/jbc.M112.415398

Christodoulou, J., Grimm, A., Maher, T., and Bennetts, B. (2003). RettBASE: the IRSA MECP2 variation database-a new mutation database in evolution. Hum. Mutat. 21, 466-472. doi: 10.1002/humu.10194

Cohen, S., Gabel, H. W., Hemberg, M., Hutchinson, A. N., Sadacca, L. A., Ebert, D. H., et al. (2011). Genome-wide activity-dependent MeCP2 phosphorylation 
regulates nervous system development and function. Neuron $72,72-85$. doi: 10.1016/j.neuron.2011.08.022

Costa, Y., Ding, J., Theunissen, T. W., Faiola, F., Hore, T. A., Shliaha, P. V., et al. (2013). NANOG-dependent function of TET1 and TET2 in establishment of pluripotency. Nature 495, 370-374. doi: 10.1038/nature11925

Cross, S. H., Meehan, R. R., Nan, X., and Bird, A. (1997). A component of the transcriptional repressor MeCP1 shares a motif with DNA methyltransferase and HRX proteins. Nat. Genet. 16, 256-259. doi: 10.1038/ng0797-256

Daniel, J. M., and Reynolds, A. B. (1999). The catenin p120(ctn) interacts with Kaiso, a novel BTB/POZ domain zinc finger transcription factor. Mol. Cell. Biol. 19, 3614-3623. doi: 10.1128/MCB.19.5.3614

Daniel, J. M., Spring, C. M., Crawford, H. C., Reynolds, A. B., and Baig, A. (2002). The p120(ctn)-binding partner Kaiso is a bi-modal DNA-binding protein that recognizes both a sequence-specific consensus and methylated CpG dinucleotides. Nucleic Acids Res. 30, 2911-2919. doi: 10.1093/nar/gkf398

Daskalos, A., Oleksiewicz, U., Filia, A., Nikolaidis, G., Xinarianos, G., Gosney, J. R., et al. (2011). UHRF1-mediated tumor suppressor gene inactivation in nonsmall cell lung cancer. Cancer 117, 1027-1037. doi: 10.1002/cncr.25531

Dawlaty, M. M., Breiling, A., Le, T., Raddatz, G., Inmaculada, M., Cheng, A. W., et al. (2014). Combined deficiency of Tet 1 and Tet2 causes epigenetic abnormalities but is compatible with postnatal development. Dev. Cell 24, 310-323. doi: 10.1016/j.devcel.2012.12.015.Combined

Dawlaty, M. M., Ganz, K., Powell, B. E., Hu, Y. C., Markoulaki, S., Cheng, A. W., et al. (2011). Tetl is dispensable for maintaining pluripotency and its loss is compatible with embryonic and postnatal development. Cell Stem Cell 9, 166-175. doi: 10.1016/j.stem.2011.07.010

de Rojas-Walker, T., Tamir, S., Ji, H., Wishnok, J. S., and Tannenbaum, S. R. (1995). Nitric oxide induces oxidative damage in addition to deamination in macrophage DNA. Chem. Res. Toxicol. 8, 473-477. doi: 10.1021/tx00045a020

Deplus, R., Delatte, B., Schwinn, M. K., Defrance, M., Mendez, J., Murphy, N., et al. (2013). TET2 and TET3 regulate GlcNAcylation and H3K4 methylation through OGT and SET1/COMPASS. EMBO J. 32, 645-655. doi: $10.1038 /$ emboj.2012.357

Doege, C. A., Inoue, K., Yamashita, T., Rhee, D. B., Travis, S., Fujita, R., et al. (2012). Early-stage epigenetic modification during somatic cell reprogramming by Parp1 and Tet2. Nature 488, 652-655. doi: 10.1038/nature11333

dos Santos, R. L., Tosti, L., Radzisheuskaya, A., Caballero, I. M., Kaji, K., Hendrich, B., et al. (2014). MBD3/NuRD facilitates induction of pluripotency in a context-dependent manner. Cell Stem Cell 15, 102-110. doi: 10.1016/j.stem.2014.04.019

Dragich, J. M., Kim, Y. H., Arnold, A. P., and Schanen, N. C. (2007). Differential distribution of the MeCP2 splice variants in the postnatal mouse brain. J. Comp. Neurol. 501, 526-542. doi: 10.1002/cne.21264

Easwaran, H. P., Schermelleh, L., Leonhardt, H., and Cardoso, M. C. (2004). Replication-independent chromatin loading of Dnmt1 during G2 and M phases. EMBO Rep. 5, 1181-1186. doi: 10.1038/sj.embor.7400295

Ebert, D. H., Gabel, H. W., Robinson, N. D., Kastan, N. R., Hu, L. S., Cohen, S., et al. (2013). Activity-dependent phosphorylation of MeCP2 threonine 308 regulates interaction with NCoR. Nature 499, 341-345. doi: 10.1038/nature12348

Filion, G. J., Zhenilo, S., Salozhin, S., Yamada, D., Prokhortchouk, E., and Defossez, P. A. (2006). A family of human zinc finger proteins that bind methylated DNA and repress transcription. Mol. Cell. Biol. 26, 169-181. doi: 10.1128/MCB.26.1.169-181.2006

Frauer, C., Hoffmann, T., Bultmann, S., Casa, V., Cardoso, M. C., Antes, I., et al. (2011a). Recognition of 5-hydroxymethylcytosine by the Uhrf1 SRA domain. PLoS ONE 6:e21306. doi: 10.1371/journal.pone.0021306

Frauer, C., Rottach, A., Meilinger, D., Bultmann, S., Fellinger, K., Hasenöder, S., et al. (2011b). Different binding properties and function of CXXC zinc finger domains in Dnmtl and Tet1. PLOS ONE 6:e16627. doi: 10.1371/journal.pone.0016627

Fujimori, A., Matsuda, Y., Takemoto, Y., Hashimoto, Y., Kubo, E., Araki, R., et al. (1998). Cloning and mapping of Np95 gene which encodes a novel nuclear protein associated with cell proliferation. Mamm. Genome 9, 1032-1035. doi: $10.1007 / \mathrm{s} 003359900920$

Fujita, N., Takebayashi, S., Okumura, K., Kudo, S., Chiba, T., Saya, H., et al. (1999). Methylation-mediated transcriptional silencing in euchromatin by methylCpG binding protein MBD1 isoforms. Mol. Cell. Biol. 19, 6415-6426. doi: 10.1128/MCB.19.9.6415
Fujita, N., Watanabe, S., Ichimura, T., Tsuruzoe, S., Shinkai, Y., Tachibana, M., et al. (2003). Methyl-CpG binding domain 1 (MBD1) interacts with the Suv39h1HP1 heterochromatic complex for DNA methylation-based transcriptional repression. J. Biol. Chem. 278, 24132-24138. doi: 10.1074/jbc.M302283200

Fuks, F., Hurd, P. J., Wolf, D., Nan, X., Bird, A. P., and Kouzarides, T. (2003). The methyl-CpG-binding protein MeCP2 links DNA methylation to histone methylation. J. Biol. Chem. 278, 4035-4040. doi: 10.1074/jbc.M210256200

Gao, Y., Chen, J., Li, K., Wu, T., Huang, B., Liu, W., et al. (2013). Replacement of Oct4 by Tet1 during iPSC induction reveals an important role of DNA methylation and hydroxymethylation in reprogramming. Cell Stem Cell 12, 453-469. doi: 10.1016/j.stem.2013.02.005

Georgel, P. T., Horowitz-Scherer, R. A., Adkins, N., Woodcock, C. L., Wade, P. A., and Hansen, J. C. (2003). Chromatin compaction by human MeCP2. Assembly of novel secondary chromatin structures in the absence of DNA methylation. J. Biol. Chem. 278, 32181-32188. doi: 10.1074/jbc.M305308200

Ghosh, R. P., Nikitina, T., Horowitz-Scherer, R. A., Gierasch, L. M., Uversky, V. N., Hite, K., et al. (2010). Unique physical properties and interactions of the domains of methylated DNA binding protein 2. Biochemistry 49, 4395-4410. doi: 10.1021/bi9019753

Gnanapragasam, M. N., Scarsdale, J. N., Amaya, M. L., Webb, H. D., Desai, M. A., Walavalkar, N. M., et al. (2011). p66Alpha-MBD2 coiled-coil interaction and recruitment of $\mathrm{Mi}-2$ are critical for globin gene silencing by the MBD2-NuRD complex. Proc. Natl. Acad. Sci. U.S.A. 108, 7487-7492. doi: 10.1073/pnas.1015341108

Goll, M. G., Kirpekar, F., Maggert, K. A., Yoder, J. A., Hsieh, C.-L., Zhang, X., et al. (2006). Methylation of tRNAAsp by the DNA methyltransferase homolog Dnmt2. Science 311, 395-398. doi: 10.1126/science.1120976

Gonzales, M. L., Adams, S., Dunaway, K. W., and LaSalle, J. M. (2012). Phosphorylation of distinct sites in MeCP2 modifies cofactor associations and the dynamics of transcriptional regulation. Mol. Cell. Biol. 32, 2894-2903. doi: 10.1128/MCB.06728-11

Grohmann, M., Spada, F., Schermelleh, L., Alenina, N., Bader, M., Cardoso, M. C., et al. (2005). Restricted mobility of Dnmt1 in preimplantation embryos: implications for epigenetic reprogramming. BMC Dev. Biol. 5:18. doi: 10.1186/1471-213X-5-18

Gu, T. P., Guo, F., Yang, H., Wu, H. P., Xu, G. F., Liu, W., et al. (2011). The role of Tet3 DNA dioxygenase in epigenetic reprogramming by oocytes. Nature 477, 606-610. doi: 10.1038/nature10443

Gunther, K., Rust, M., Leers, J., Boettger, T., Scharfe, M., Jarek, M., et al. (2013). Differential roles for MBD2 and MBD3 at methylated $\mathrm{CpG}$ islands, active promoters and binding to exon sequences. Nucleic Acids Res. 41, 3010-3021. doi: 10.1093/nar/gkt035

Guo, J. U., Su, Y., Shin, J. H., Shin, J., Li, H., Xie, B., et al. (2014). Distribution, recognition and regulation of non-CpG methylation in the adult mammalian brain. Nat. Neurosci. 17, 215-222. doi: 10.1038/nn.3607

Guo, J. U., Su, Y., Zhong, C., Ming, G. L., and Song, H. (2011). Hydroxylation of 5 -methylcytosine by TET1 promotes active DNA demethylation in the adult brain. Cell 145, 423-434. doi: 10.1016/j.cell.2011.03.022

Guy, J., Gan, J., Selfridge, J., Cobb, S., and Bird, A. (2007). Reversal of neurological defects in a mouse model of Rett syndrome. Science 315, 1143-1147. doi: 10.1126/science. 1138389

Guy, J., Hendrich, B., Holmes, M., Martin, J. E., and Bird, A. (2001). A mouse Mecp2-null mutation causes neurological symptoms that mimic Rett syndrome. Nat. Genet. 27, 322-326. doi: 10.1038/85899

Hackett, J. A., Sengupta, R., Zylicz, J. J., Murakami, K., Lee, C., Down, T. A., et al. (2013). Germline DNA demethylation dynamics and imprint erasure through 5-hydroxymethylcytosine. Science 339, 448-452. doi: 10.1126/science.1229277

Haffner, M. C., Chaux, A., Meeker, A. K., Esopi, D. M., Gerber, J., Pellakuru, L. G., et al. (2011). Global 5-hydroxymethylcytosine content is significantly reduced in tissue stem/progenitor cell compartments and in human cancers. Oncotarget 2, 627-637. doi: 10.18632/oncotarget.316

Hagberg, B., Aicardi, J., Dias, K., and Ramos, O. (1983). A progressive syndrome of autism, dementia, ataxia, and loss of purposeful hand use in girls: rett's syndrome: report of 35 cases. Ann. Neurol. 14, 471-479. doi: $10.1002 /$ ana.410140412

Hajkova, P., Erhardt, S., Lane, N., Haaf, T., El-Maarri, O., Reik, W., et al. (2002). Epigenetic reprogramming in mouse primordial germ cells. Mech. Dev. 117, 15-23. doi: 10.1016/S0925-4773(02)00181-8 
Hamiche, A., Schultz, P., Ramakrishnan, V., Oudet, P., and Prunell, A. (1996). Linker histone-dependent DNA structure in linear mononucleosomes. J. Mol. Biol. 257, 30-42. doi: 10.1006/jmbi.1996.0144

Hansen, R. S., Wijmenga, C., Luo, P., Stanek, A. M., Canfield, T. K., Weemaes, C. M., et al. (1999). The DNMT3B DNA methyltransferase gene is mutated in the ICF immunodeficiency syndrome. Proc. Natl. Acad. Sci. U.S.A. 96, 14412-14417. doi: 10.1073/pnas.96.25.14412

Hashimoto, H., Horton, J. R., Zhang, X., Bostick, M., Jacobsen, S. E., and Cheng, X. (2008). The SRA domain of UHRF1 flips 5-methylcytosine out of the DNA helix. Nature 455, 826-829. doi: 10.1038/nature07280

Hashimoto, H., Horton, J. R., Zhang, X., and Cheng, X. (2009). UHRF1, a modular multi-domain protein, regulates replication-coupled crosstalk between DNA methylation and histone modifications. Epigenetics 4, 8-14. doi: 10.4161/epi.4.1.7370

Hashimoto, H., Liu, Y., Upadhyay, A. K., Chang, Y., Howerton, S. B., Vertino, P. M., et al. (2012a). Recognition and potential mechanisms for replication and erasure of cytosine hydroxymethylation. Nucleic Acids Res. 40, 4841-4849. doi: 10.1093/nar/gks155

Hashimoto, H., Pais, J. E., Dai, N., Corrêa, I. R., Zhang, X., Zheng, Y., et al. (2015). Structure of Naegleria Tet-like dioxygenase (NgTet1) in complexes with a reaction intermediate 5-hydroxymethylcytosine DNA. Nucleic Acids Res. 43, 10713-10721. doi: 10.1093/nar/gkv870

Hashimoto, H., Pais, J. E., Zhang, X., Saleh, L., Fu, Z. Q., Dai, N., et al. (2014). Structure of a Naegleria Tet-like dioxygenase in complex with 5-methylcytosine DNA. Nature 506, 391-395. doi: 10.1038/nature12905

Hashimoto, H., Zhang, X., and Cheng, X. (2012b). Excision of thymine and 5hydroxymethyluracil by the MBD4 DNA glycosylase domain: structural basis and implications for active DNA demethylation. Nucleic Acids Res. 40, 82768284. doi: 10.1093/nar/gks628

He, X., Duan, C., Chen, J., Ou-Yang, X., Zhang, Z., Li, C., et al. (2009). Let-7a elevates p21(WAF1) levels by targeting of NIRF and suppresses the growth of A549 lung cancer cells. FEBS Lett. 583, 3501-3507. doi: 10.1016/j.febslet.2009.10.007

He, Y. F., Li, B. Z., Li, Z., Liu, P., Wang, Y., Tang, Q., et al. (2011). Tet-mediated formation of 5-carboxylcytosine and its excision by TDG in mammalian DNA. Science 333, 1303-1307. doi: 10.1126/science. 1210944

Hendrich, B., and Bird, A. (1998). Identification and characterization of a family of mammalian methyl-CpG binding proteins. Mol. Cell. Biol. 18, 6538-6547. doi: 10.1128/MCB.18.11.6538

Hendrich, B., Guy, J., Ramsahoye, B., Wilson, V. A., and Bird, A. (2001). Closely related proteins MBD2 and MBD3 play distinctive but interacting roles in mouse development. Genes Dev. 15, 710-723. doi: 10.1101/gad.194101

Hendrich, B., Hardeland, U., Ng, H. H., Jiricny, J., and Bird, A. (1999). The thymine glycosylase MBD4 can bind to the product of deamination at methylated $\mathrm{CpG}$ sites. Nature 401, 301-304. doi: 10.1038/45843

Hendrich, B., and Tweedie, S. (2003). The methyl-CpG binding domain and the evolving role of DNA methylation in animals. Trends Genet. 19, 269-277. doi: 10.1016/S0168-9525(03)00080-5

Hopfner, R., Mousli, M., Jeltsch, J. M., Voulgaris, A., Lutz, Y., Marin, C., et al. (2000). ICBP90, a novel human CCAAT binding protein, involved in the regulation of topoisomerase IIalpha expression. Cancer Res. 60, 121-128.

Hotchkiss, D. (1948). THE QUANTITATIVE SEPARATION OF PURINES, and NUCLEOSIDES BY paper chromatography. J. Biol. Chem. 175, 315-332.

Hu, L., Li, Z., Cheng, J., Rao, Q., Gong, W., Liu, M., et al. (2013). Crystal structure of TET2-DNA complex: insight into TET-mediated $5 \mathrm{mC}$ oxidation. Cell 155, 1545-1555. doi: 10.1016/j.cell.2013.11.020

Hu, L., Li, Z., Wang, P., Lin, Y., and Xu, Y. (2011). Crystal structure of PHD domain of UHRF1 and insights into recognition of unmodified histone $\mathrm{H} 3$ arginine residue 2. Cell Res. 21, 1374-1378. doi: 10.1038/cr.2011.124

Hu, L., Lu, J., Cheng, J., Rao, Q., Li, Z., Hou, H., et al. (2015). Structural insight into substrate preference for TET-mediated oxidation. Nature 527, 118-122. doi: $10.1038 /$ nature 15713

Hu, Y. G., Hirasawa, R., Hu, J. L., Hata, K., Li, C. L., Jin, Y., et al. (2008). Regulation of DNA methylation activity through Dnmt3L promoter methylation by Dnmt3 enzymes in embryonic development. Hum. Mol. Genet. 17, 2654-2664. doi: $10.1093 / \mathrm{hmg} / \mathrm{ddn} 165$
Huang, H., Jiang, X., Li, Z., Li, Y., Song, C.-X., He, C., et al. (2013). TET1 plays an essential oncogenic role in MLL-rearranged leukemia. Proc. Natl. Acad. Sci. U.S.A. 110, 11994-11999. doi: 10.1073/pnas.1310656110

Huang, Y., Chavez, L., Chang, X., Wang, X., Pastor, W. A., Kang, J., et al. (2014). Distinct roles of the methylcytosine oxidases Tet1 and Tet2 in mouse embryonic stem cells. Proc. Natl. Acad. Sci. U.S.A. 111, 1361-1366. doi: 10.1073/pnas.1322921111

Inano, K., Suetake, I., Ueda, T., Miyake, Y., Nakamura, M., Okada, M., et al. (2000). Maintenance-type DNA methyltransferase is highly expressed in postmitotic neurons and localized in the cytoplasmic compartment. J. Biochem. 128, 315-321. doi: 10.1093/oxfordjournals.jbchem.a022755

Iqbal, K., Jin, S. G., Pfeifer, G. P., and Szabo, P. E. (2011). Reprogramming of the paternal genome upon fertilization involves genome-wide oxidation of 5-methylcytosine. Proc. Natl. Acad. Sci. U.S.A. 108, 3642-3647. doi: 10.1073/pnas. 1014033108

Ito, R., Katsura, S., Shimada, H., Tsuchiya, H., Hada, M., Okumura, T., et al. (2014). TET3-OGT interaction increases the stability and the presence of OGT in chromatin. Genes Cells 19, 52-65. doi: 10.1111/gtc.12107

Ito, S., D’Alessio, A. C., Taranova, O. V., Hong, K., Sowers, L. C., and Zhang, Y. (2010). Role of tet proteins in $5 \mathrm{mC}$ to $5 \mathrm{hmC}$ conversion, ES-cell self-renewal and inner cell mass specification. Nature 466, 1129-1133. doi: 10.1038 /nature09303

Ito, S., Shen, L., Dai, Q., Wu, S. C., Collins, L. B., Swenberg, J. A., et al. (2011). Tet proteins can convert 5-methylcytosine to 5-formylcytosine and 5-carboxylcytosine. Science 333, 1300-1303. doi: 10.1126/science.1210597

Jin, C., Lu, Y., Jelinek, J., Liang, S., Estecio, M. R. H., Barton, M. C., et al. (2014). TET1 is a maintenance DNA demethylase that prevents methylation spreading in differentiated cells. Nucleic Acids Res. 42, 6956-6971. doi: 10.1093/nar/gku372

Jin, S. G., Wu, X., Li, A. X., and Pfeifer, G. P. (2011). Genomic mapping of 5hydroxymethylcytosine in the human brain. Nucleic Acids Res. 39, 5015-5024. doi: 10.1093/nar/gkr120

Johnson, L. M., Bostick, M., Zhang, X., Kraft, E., Henderson, I., Callis, J., et al. (2007). The SRA methyl-cytosine-binding domain links DNA and histone methylation. Curr. Biol. 17, 379-384. doi: 10.1016/j.cub.2007.01.009

Jones, P. L., Veenstra, G. J., Wade, P. A., Vermaak, D., Kass, S. U., Landsberger, N., et al. (1998). Methylated DNA and MeCP2 recruit histone deacetylase to repress transcription. Nat. Genet. 19, 187-191. doi: 10.1038/561

Jorgensen, H. F., Ben-Porath, I., and Bird, A. P. (2004). Mbd1 is recruited to both methylated and nonmethylated CpGs via distinct DNA binding domains. Mol. Cell. Biol. 24, 3387-3395. doi: 10.1128/MCB.24.8.3387-3395.2004

Jung, B. P., Jugloff, D. G., Zhang, G., Logan, R., Brown, S., and Eubanks, J. H. (2003). The expression of methyl CpG binding factor MeCP2 correlates with cellular differentiation in the developing rat brain and in cultured cells. J. Neurobiol. 55, 86-96. doi: 10.1002/neu.10201

Jung, S. Y., Li, Y., Wang, Y., Chen, Y., Zhao, Y., and Qin, J. (2008). Complications in the assignment of 14 and 28 Da mass shift detected by mass spectrometry as in vivo methylation from endogenous proteins. Anal. Chem. 80, 1721-1729. doi: $10.1021 / \mathrm{ac} 7021025$

Kaji, K., Caballero, I. M., MacLeod, R., Nichols, J., Wilson, V. A., and Hendrich, B. (2006). The NuRD component Mbd3 is required for pluripotency of embryonic stem cells. Nat. Cell Biol. 8, 285-292. doi: 10.1038/ncb1372

Kaludov, N. K., and Wolffe, A. P. (2000). MeCP2 driven transcriptional repression in vitro: selectivity for methylated DNA, action at a distance and contacts with the basal transcription machinery. Nucleic Acids Res. 28, 1921-1928. doi: 10.1093/nar/28.9.1921

Karagianni, P., Amazit, L., Qin, J., and Wong, J. (2008). ICBP90, a novel methyl K9 H3 binding protein linking protein ubiquitination with heterochromatin formation. Mol. Cell. Biol. 28, 705-717. doi: 10.1128/MCB.01598-07

Kemmerich, K., Dingler, F. A., Rada, C., and Neuberger, M. S. (2012). Germline ablation of SMUG1 DNA glycosylase causes loss of 5-hydroxymethyluracil- and UNG-backup uracil-excision activities and increases cancer predisposition of Ung-/-Msh2-/- mice. Nucleic Acids Res. 40, 6016-6025. doi: 10.1093/nar/gks259

Kiefer, H., Chatail-Hermitte, F., Ravassard, P., Bayard, E., Brunet, I., and Mallet, J. (2005). ZENON, a novel POZ Kruppel-like DNA binding protein associated with differentiation and/or survival of late postmitotic neurons. Mol. Cell. Biol. 25, 1713-1729. doi: 10.1128/MCB.25.5.1713-1729.2005 
Kienhöfer, S., Musheev, M. U., Stapf, U., Helm, M., Schomacher, L., Niehrs, C., et al. (2015). GADD45a physically and functionally interacts with TET1. Differentiation 90, 59-68. doi: 10.1016/j.diff.2015.10.003

Kim, J. K., Esteve, P. O., Jacobsen, S. E., and Pradhan, S. (2009). UHRF1 binds G9a and participates in p21 transcriptional regulation in mammalian cells. Nucleic Acids Res. 37, 493-505. doi: 10.1093/nar/gkn961

Kim, S. W., Park, J. I., Spring, C. M., Sater, A. K., Ji, H., Otchere, A. A., et al. (2004). Non-canonical Wnt signals are modulated by the Kaiso transcriptional repressor and p120-catenin. Nat. Cell Biol. 6, 1212-1220. doi: 10.1038/ncb1191

Kimura, H., and Shiota, K. (2003). Methyl-CpG-binding protein, MeCP2, is a target molecule for maintenance DNA methyltransferase, Dnmt1. J. Biol. Chem. 278, 4806-4812. doi: 10.1074/jbc.M209923200

Klein, C. J., Bird, T., Ertekin-Taner, N., Lincoln, S., Hjorth, R., Wu, Y., et al. (2013). DNMT1 mutation hot spot causes varied phenotypes of HSAN1 with dementia and hearing loss. Neurology 80, 824-828. doi: 10.1212/WNL.0b013e31828

Klein, C. J., Botuyan, M. V., Wu, Y., Ward, C. J., Nicholson, G. A., Hammans, S., et al. (2011). Mutations in DNMT1 cause hereditary sensory neuropathy with dementia and hearing loss. Nat. Genet. 43, 595-600. doi: 10.1038/ng.830

Ko, M., An, J., Bandukwala, H. S., Chavez, L., Aijö, T., Pastor, W. A., et al. (2013). Modulation of TET2 expression and 5-methylcytosine oxidation by the CXXC domain protein IDAX. Nature 497, 122-126. doi: 10.1038/nature12052

Ko, M., Huang, Y., Jankowska, A. M., Pape, U. J., Tahiliani, M., Bandukwala, H. S., et al. (2010). Impaired hydroxylation of 5-methylcytosine in myeloid cancers with mutant TET2. Nature 468, 839-843. doi: 10.1038/nature09586

Kokura, K., Kaul, S. C., Wadhwa, R., Nomura, T., Khan, M. M., Shinagawa, T., et al. (2001). The Ski protein family is required for MeCP2-mediated transcriptional repression. J. Biol. Chem. 276, 34115-34121. doi: 10.1074/jbc.M105747200

Konstandin, N., Bultmann, S., Szwagierczak, A., Dufour, A., Ksienzyk, B., Schneider, F., et al. (2011). Genomic 5-hydroxymethylcytosine levels correlate with TET2 mutations and a distinct global gene expression pattern in secondary acute myeloid leukemia. Leukemia 25, 1649-1652. doi: 10.1038/leu.2011.134leu2011134

Koziol, M. J., Bradshaw, C. R., Allen, G. E., Costa, A. S., Frezza, C., and Gurdon, J. B. (2016). Identification of methylated deoxyadenosines in vertebrates reveals diversity in DNA modifications. Nat. Struct. Mol. Biol. 23, 24-30. doi: 10.1038/nsmb.3145

Kraus, T. F. J., Globisch, D., Wagner, M., Eigenbrod, S., Widmann, D., Münzel, M., et al. (2012). Low values of 5-hydroxymethylcytosine (5hmC), the "sixth base," are associated with anaplasia in human brain tumors. Int. J. Cancer 131, 1577-1590. doi: 10.1002/ijc.27429

Kriaucionis, S., and Bird, A. (2004). The major form of MeCP2 has a novel $\mathrm{N}$-terminus generated by alternative splicing. Nucleic Acids Res. 32, 1818-1823. doi: 10.1093/nar/gkh349

Kriaucionis, S., and Heintz, N. (2009). The nuclear DNA base 5hydroxymethylcytosine is present in Purkinje neurons and the brain. Science 324, 929-930. doi: 10.1126/science.1169786

Kumar, S., Cheng, X., Klimasauskas, S., Mi, S., Posfai, J., Roberts, R. J., et al. (1994). The DNA (cytosine-5) methyltransferases. Nucleic Acids Res. 22, 1-10. doi: $10.1093 / \mathrm{nar} / 22.1 .1$

Laget, S., Joulie, M., Le Masson, F., Sasai, N., Christians, E., Pradhan, S., et al. (2010). The human proteins MBD5 and MBD6 associate with heterochromatin but they do not bind methylated DNA. PLoS ONE 5:e11982. doi: 10.1371/journal.pone.0011982

Ley, T. J., Ding, L., Walter, M. J., McLellan, M. D., Lamprecht, T., Larson, D. E., et al. (2011). DNMT3A Mutations in Acute Myeloid Leukemia. N. Engl. J. Med. 363, 2424-2433. doi: 10.1056/NEJMoa1005143

Langemeijer, S., Kuiper, R., Berends, M., Knops, R., Aslanyan, M., Massop, M., et al. (2009). Acquired mutations in TET2 are common in myelodysplastic syndromes. Leuk. Res. 33, 838-842. doi: 10.1016/S0145-2126(09)70 $132-8$

Le Guezennec, X., Vermeulen, M., Brinkman, A. B., Hoeijmakers, W. A., Cohen, A., Lasonder, E., et al. (2006). MBD2/NuRD and MBD3/NuRD, two distinct complexes with different biochemical and functional properties. Mol. Cell. Biol. 26, 843-851. doi: 10.1128/MCB.26.3.843-851.2006

Lee, J. H., and Skalnik, D. G. (2002). CpG-binding protein is a nuclear matrix- and euchromatin-associated protein localized to nuclear speckles containing human trithorax. Identification of nuclear matrix targeting signals. J. Biol. Chem. 277, 42259-42267. doi: 10.1074/jbc.M205054200
Lee, J. H., and Skalnik, D. G. (2005). CpG-binding protein (CXXC finger protein 1) is a component of the mammalian Set1 histone H3-Lys4 methyltransferase complex, the analogue of the yeast Set1/COMPASS complex. J. Biol. Chem. 280, 41725-41731. doi: 10.1074/jbc.M508312200

Leonhardt, H., Page, A. W., Weier, H. U., and Bestor, T. H. (1992). A targeting sequence directs DNA methyltransferase to sites of DNA replication in mammalian nuclei. Cell 71, 865-873. doi: 10.1016/0092-8674(92)90561-P

Lewis, J. D., Meehan, R. R., Henzel, W. J., Maurer-Fogy, I., Jeppesen, P., Klein, F., et al. (1992). Purification, sequence, and cellular localization of a novel chromosomal protein that binds to methylated DNA. Cell 69, 905-914. doi: 10.1016/0092-8674(92)90610-O

Li, D., Qiu, Z., Shao, Y., Chen, Y., Guan, Y., Liu, M., et al. (2013). Heritable gene targeting in the mouse and rat using a CRISPR-Cas system. Nat. Biotechnol. 31, 681-683. doi: 10.1038/nbt.2661

Li, E., Bestor, T. H., and Jaenisch, R. (1992). Targeted mutation of the DNA methyltransferase gene results in embryonic lethality. Cell 69, 915-926. doi: 10.1016/0092-8674(92)90611-F

Li, H., and Chang, Q. (2014). Regulation and function of stimulusinduced phosphorylation of MeCP2. Front. Biol. (Beijing) 9:367-375. doi: 10.1007/s11515-014-1330-2

Li, W., and Liu, M. (2011). Distribution of 5-hydroxymethylcytosine in different human tissues. J. Nucleic Acids 2011, 870726. doi: 10.4061/2011/870726

Li, Z., Cai, X., Cai, C. L., Wang, J., Zhang, W., Petersen, B. E., et al. (2011). Deletion of Tet2 in mice leads to dysregulated hematopoietic stem cells and subsequent development of myeloid malignancies. Blood 118, 4509-4518. doi: 10.1182/blood-2010-12-325241

Li, Z., Gu, T. P., Weber, A. R., Shen, J. Z., Li, B. Z., Xie, Z. G., et al. (2015). Gadd45a promotes DNA demethylation through TDG. Nucleic Acids Res. 43, 3986-3997. doi: $10.1093 / \mathrm{nar} / \mathrm{gkv} 283$

Lin, R. K., Hsu, H. S., Chang, J. W., Chen, C. Y., Chen, J. T., and Wang, Y. C. (2007). Alteration of DNA methyltransferases contributes to 5'CpG methylation and poor prognosis in lung cancer. Lung Cancer 55, 205-213. doi: 10.1016/j.lungcan.2006.10.022

Liu, N., Wang, M., Deng, W., Schmidt, C. S., Qin, W., Leonhardt, H., et al. (2013). Intrinsic and extrinsic connections of Tet 3 dioxygenase with CXXC zinc finger modules. PLoS ONE 8:e62755. doi: 10.1371/journal.pone.0062755

Liu, Y., Oakeley, E. J., Sun, L., and Jost, J. P. (1998). Multiple domains are involved in the targeting of the mouse DNA methyltransferase to the DNA replication foci. Nucleic Acids Res. 26, 1038-1045. doi: 10.1093/nar/26.4.1038

Loat, C. S., Curran, S., Lewis, C. M., Duvall, J., Geschwind, D., Bolton, P., et al. (2008). Methyl-CpG-binding protein 2 polymorphisms and vulnerability to autism. Genes Brain Behav. 7, 754-760. doi: 10.1111/j.1601-183X.2008. 00414.x

Lopes, E. C., Valls, E., Figueroa, M. E., Mazur, A., Meng, F. G., Chiosis, G., et al. (2008). Kaiso contributes to DNA methylation-dependent silencing of tumor suppressor genes in colon cancer cell lines. Cancer Res. 68, 7258-7263. doi: 10.1158/0008-5472.CAN-08-0344

Lorsbach, R. B., Moore, J., Mathew, S., Raimondi, S. C., Mukatira, S. T., and Downing, J. R. (2003). TET1, a member of a novel protein family, is fused to MLL in acute myeloid leukemia containing the $\mathrm{t}(10 ; 11)$ (q22;q23). Leukemia 17, 637-641. doi: 10.1038/sj.leu.2402834

Lu, J., Hu, L., Cheng, J., Dong, F., Wang, C., Yu, K., et al. (2016). A computational investigation on the substrate preference of TET2. Phys. Chem. Chem. Phys 18, 4728-4738. doi: 10.1039/C5CP07266B

Lunyak, V. V., Burgess, R., Prefontaine, G. G., Nelson, C., Sze, S. H., Chenoweth, J., et al. (2002). Corepressor-dependent silencing of chromosomal regions encoding neuronal genes. Science 298, 1747-1752. doi: 10.1126/science.1076469

Luo, M., Ling, T., Xie, W., Sun, H., Zhou, Y., Zhu, Q., et al. (2013). NuRD blocks reprogramming of mouse somatic cells into pluripotent stem cells. Stem Cells 31, 1278-1286. doi: 10.1002/stem.1374

Lyko, F., Ramsahoye, B. H., and Jaenisch, R. (2000). DNA methylation in Drosophila melanogaster. Nature 408, 538-540. doi: 10.1038/35046205

Lyst, M. J., Ekiert, R., Ebert, D. H., Merusi, C., Nowak, J., Selfridge, J., et al. (2013). Rett syndrome mutations abolish the interaction of MeCP2 with the NCoR/SMRT co-repressor. Nat. Neurosci. 16, 898-902. doi: 10.1038/nn.3434

Lyst, M. J., Nan, X., and Stancheva, I. (2006). Regulation of MBD1-mediated transcriptional 1478 repression by SUMO and PIAS proteins. EMBO J. 25, 5317-5328. doi: 10.1038/sj.emboj.7601404 
Mahajan, M. C., Narlikar, G. J., Boyapaty, G., Kingston, R. E., and Weissman, S. M. (2005). Heterogeneous nuclear ribonucleoprotein C1/C2, MeCP1, and SWI/SNF form a chromatin remodeling complex at the beta-globin locus control region. Proc. Natl. Acad. Sci. U.S.A. 102, 15012-15017. doi: 10.1073/pnas.0507596102

Maiti, A., and Drohat, A. C. (2011). Thymine DNA glycosylase can rapidly excise 5-formylcytosine and 5-carboxylcytosine: potential implications for active demethylation of CpG sites. J. Biol. Chem. 286, 35334-35338. doi: 10.1074/jbc.C111.284620

Marhold, J., Kramer, K., Kremmer, E., and Lyko, F. (2004). The Drosophila MBD2/3 protein mediates interactions between the MI-2 chromatin complex and CpT/A-methylated DNA. Development 131, 6033-6039. doi: 10.1242/dev. 01531

Martinowich, K., Hattori, D., Wu, H., Fouse, S., He, F., Hu, Y., et al. (2003). DNA methylation-related chromatin remodeling in activity-dependent BDNF gene regulation. Science 302, 890-893. doi: 10.1126/science.1090842

Mayer, W., Niveleau, A., Walter, J., Fundele, R., and Haaf, T. (2000). Demethylation of the zygotic paternal genome. Nature 403, 501-502. doi: 10.1038/35000654

Meehan, R. R., Lewis, J. D., and Bird, A. P. (1992). Characterization of MeCP2, a vertebrate DNA binding protein with affinity for methylated DNA. Nucleic Acids Res. 20, 5085-5092. doi: 10.1093/nar/20.19.5085

Meehan, R. R., Lewis, J. D., McKay, S., Kleiner, E. L., and Bird, A. P. (1989). Identification of a mammalian protein that binds specifically to DNA containing methylated CpGs. Cell 58, 499-507. doi: 10.1016/00928674(89)90430-3

Meilinger, D., Fellinger, K., Bultmann, S., Rothbauer, U., Bonapace, I. M., Klinkert, W. E., et al. (2009). Np95 interacts with de novo DNA methyltransferases, Dnmt3a and Dnmt3b, and mediates epigenetic silencing of the viral CMV promoter in embryonic stem cells. EMBO Rep. 10, 1259-1264. doi: 10.1038/embor.2009.201

Mellen, M., Ayata, P., Dewell, S., Kriaucionis, S., and Heintz, N. (2012). MeCP2 binds to $5 \mathrm{hmC}$ enriched within active genes and accessible chromatin in the nervous system. Cell 151, 1417-1430. doi: 10.1016/j.cell.2012.11.022

Mertineit, C., Yoder, J. A., Taketo, T., Laird, D. W., Trasler, J. M., and Bestor, T. H. (1998). Sex-specific exons control DNA methyltransferase in mammalian germ cells. Development $125,889-897$.

Michaels, M. L., Pham, L., Nghiem, Y., Cruz, C., and Miller, J. H. (1990). MutY, an adenine glycosylase active on G-A mispairs, has homology to endonuclease III. Nucleic Acids Res. 18, 3841-3845. doi: 10.1093/nar/18.13.3841

Millar, C. B., Guy, J., Sansom, O. J., Selfridge, J., MacDougall, E., Hendrich, B., et al. (2002). Enhanced CpG mutability and tumorigenesis in MBD4-deficient mice. Science 297, 403-405. doi: 10.1126/science.1073354

Mnatzakanian, G. N., Lohi, H., Munteanu, I., Alfred, S. E., Yamada, T., MacLeod, P. J., et al. (2004). A previously unidentified MECP2 open reading frame defines a new protein isoform relevant to Rett syndrome. Nat. Genet. 36, 339-341. doi: $10.1038 / \mathrm{ng} 1327$

Mori, T., Ikeda, D. D., Yamaguchi, Y., Unoki, M., and Project, N. (2012). NIRF/UHRF2 occupies a central position in the cell cycle network and allows coupling with the epigenetic landscape. FEBS Lett. 586, 1570-1583. doi: 10.1016/j.febslet.2012.04.038

Mori, T., Li, Y., Hata, H., Ono, K., and Kochi, H. (2002). NIRF, a novel RING finger protein, is involved in cell-cycle regulation. Biochem. Biophys. Res. Commun. 296, 530-536. doi: 10.1016/S0006-291X(02)00890-2

Muller, H. M., Fiegl, H., Goebel, G., Hubalek, M. M., Widschwendter, A., MullerHolzner, E., et al. (2003). MeCP2 and MBD2 expression in human neoplastic and non-neoplastic breast tissue and its association with oestrogen receptor status. Br. J. Cancer 89, 1934-1939. doi: 10.1038/sj.bjc.6601392

Muller, U., Bauer, C., Siegl, M., Rottach, A., and Leonhardt, H. (2014). TETmediated oxidation of methylcytosine causes TDG or NEIL glycosylase dependent gene reactivation. Nucleic Acids Res. 42, 8592-8604. doi: $10.1093 / \mathrm{nar} / \mathrm{gku} 552$

Muotri, A. R., Marchetto, M. C., Coufal, N. G., Oefner, R., Yeo, G., Nakashima, K., et al. (2010). L1 retrotransposition in neurons is modulated by MeCP2. Nature 468, 443-446. doi: 10.1038/nature09544

Nady, N., Lemak, A., Walker, J. R., Avvakumov, G. V., Kareta, M. S., Achour, M., et al. (2011). Recognition of multivalent histone states associated with heterochromatin by UHRF1 protein. J. Biol. Chem. 286, 24300-24311. doi: 10.1074/jbc.M111.234104
Nagarajan, R. P., Hogart, A. R., Gwye, Y., Martin, M. R., and LaSalle, J. M. (2006). Reduced MeCP2 expression is frequent in autism frontal cortex and correlates with aberrant MECP2 promoter methylation. Epigenetics 1, e1-e11. doi: 10.4161/epi.1.4.3514

Nakagawa, T., Lv, L., Nakagawa, M., Yu, Y., Yu, C., D’Alessio, A. C., et al. (2015). CRL4VprBP E3 ligase promotes monoubiquitylation and chromatin binding of TET dioxygenases. Mol. Cell. 57, 247-260. doi: 10.1016/j.molcel.2014.12.002

Nakamura, T., Liu, Y. J., Nakashima, H., Umehara, H., Inoue, K., Matoba, S., et al. (2012). PGC7 binds histone H3K9me2 to protect against conversion of $5 \mathrm{mC}$ to $5 \mathrm{hmC}$ in early embryos. Nature 486, 415-419. doi: 10.1038/nature11093

Nan, X., Campoy, F. J., and Bird, A. (1997). MeCP2 is a transcriptional repressor with abundant binding sites in genomic chromatin. Cell 88, 471-481. doi: 10.1016/S0092-8674(00)81887-5

Nan, X., Meehan, R. R., and Bird, A. (1993). Dissection of the methyl-CpG binding domain from the chromosomal protein MeCP2. Nucleic Acids Res. 21, 4886-4892. doi: 10.1093/nar/21.21.4886

Nan, X., Ng, H. H., Johnson, C. A., Laherty, C. D., Turner, B. M., Eisenman, R. N., et al. (1998). Transcriptional repression by the methyl-CpG-binding protein MeCP2 involves a histone deacetylase complex. Nature 393, 386-389. doi: $10.1038 / 30764$

Nestor, C. E., Ottaviano, R., Reddington, J., Sproul, D., Reinhardt, D., Dunican, D., et al. (2012). Tissue type is a major modifier of the 5-hydroxymethylcytosine content of human genes. Genome Res. 22, 467-477. doi: 10.1101/gr.126417.111

Ng, H. H., Jeppesen, P., and Bird, A. (2000). Active repression of methylated genes by the chromosomal protein MBD1. Mol. Cell. Biol. 20, 1394-1406. doi: 10.1128/MCB.20.4.1394-1406.2000

Ng, H. H., Zhang, Y., Hendrich, B., Johnson, C. A., Turner, B. M., ErdjumentBromage, H., et al. (1999). MBD2 is a transcriptional repressor belonging to the MeCP1 histone deacetylase complex. Nat. Genet. 23, 58-61. doi: 10.1038/12659

Nikitina, T., Ghosh, R. P., Horowitz-Scherer, R. A., Hansen, J. C., Grigoryev, S. A., and Woodcock, C. L. (2007a). MeCP2-chromatin interactions include the formation of chromatosome-like structures and are altered in mutations causing Rett syndrome. J. Biol. Chem. 282, 28237-28245. doi: 10.1074/jbc.M704304200

Nikitina, T., Shi, X., Ghosh, R. P., Horowitz-Scherer, R. A., Hansen, J. C., and Woodcock, C. L. (2007b). Multiple modes of interaction between the methylated DNA binding protein MeCP2 and chromatin. Mol. Cell. Biol. 27, 864-877. doi: 10.1128/MCB.01593-06

Ohki, I., Shimotake, N., Fujita, N., Nakao, M., and Shirakawa, M. (1999). Solution structure of the methyl-CpG-binding domain of the methylationdependent transcriptional repressor MBD1. EMBO J. 18, 6653-6661. doi: 10.1093/emboj/18.23.6653

Okano, M., Bell, D. W., Haber, D. A., and Li, E. (1999). DNA methyltransferases Dnmt3a and Dnmt3b are essential for de novo methylation and mammalian development. Cell 99, 247-257. doi: 10.1016/S0092-8674(00)81656-6

Okano, M., Xie, S., and Li, E. (1998). Cloning and characterization of a family of novel mammalian DNA (cytosine-5) methyltransferases. Nature Am. Inc. 19, 219-220. doi: 10.1038/890

Papait, R., Pistore, C., Grazini, U., Babbio, F., Cogliati, S., Pecoraro, D., et al. (2008). The PHD domain of Np95 (mUHRF1) is involved in large-scale reorganization of pericentromeric heterochromatin. Mol. Biol. Cell 19, 35543563. doi: 10.1091/mbc.E07-10-1059

Papait, R., Pistore, C., Negri, D., Pecoraro, D., Cantarini, L., and Bonapace, I. M. (2007). Np95 is implicated in pericentromeric heterochromatin replication and in major satellite silencing. Mol. Biol. Cell 18, 1098-1106. doi: 10.1091/mbc.E0609-0874

Park, J. I., Kim, S. W., Lyons, J. P., Ji, H., Nguyen, T. T., Cho, K., et al. (2005). Kaiso/p120-catenin and TCF/beta-catenin complexes coordinately regulate canonical Wnt gene targets. Dev. Cell 8, 843-854. doi: 10.1016/j.devcel.2005.04.010

Pastor, W. A., Pape, U. J., Huang, Y., Henderson, H. R., Lister, R., Ko, M., et al. (2011). Genome-wide mapping of 5-hydroxymethylcytosine in embryonic stem cells. Nature 473, 394-397. doi: 10.1038/nature10102

Patra, S. K., Patra, A., Zhao, H., Carroll, P., and Dahiya, R. (2003). MethylCpG-DNA binding proteins in human prostate cancer: expression of CXXC sequence containing MBD1 and repression of MBD2 and MeCP2. Biochem. Biophys. Res. Commun. 302, 759-766. doi: 10.1016/S0006-291X(03) 00253-5 
Penn, N. W., Suwalski, R., O’Riley, C., Bojanowski, K., and Yura, R. (1972). The presence of 5-hydroxymethylcytosine in animal deoxyribonucleic acid. Biochem. J. 126, 781-790. doi: 10.1042/bj1260781

Petronzelli, F., Riccio, A., Markham, G. D., Seeholzer, S. H., Stoerker, J., Genuardi, M., et al. (2000). Biphasic kinetics of the human DNA repair protein MED1 (MBD4), a mismatch-specific DNA N-glycosylase. J. Biol. Chem. 275, 32422-32429. doi: 10.1074/jbc.M004535200

Pfaffeneder, T., Hackner, B., Truss, M., Münzel, M., Müller, M., Deiml, C. A., et al. (2011). The discovery of 5-formylcytosine in embryonic stem cell DNA. Angew. Chem. Int. Edn. 50, 7008-7012. doi: 10.1002/anie.201103899

Pfaffeneder, T., Spada, F., Wagner, M., Brandmayr, C., Laube, S. K., Eisen, D., et al. (2014). Tet oxidizes thymine to 5-hydroxymethyluracil in mouse embryonic stem cell DNA. Nat. Chem. Biol. 10, 574-581. doi: 10.1038/nchembio.1532

Pichler, G., Wolf, P., Schmidt, C. S., Meilinger, D., Schneider, K., Frauer, C., et al. (2011). Cooperative DNA and histone binding by Uhrf2 links the two major repressive epigenetic pathways. J. Cell. Biochem. 112, 2585-2593. doi: $10.1002 /$ jcb. 23185

Prokhortchouk, A., Hendrich, B., Jorgensen, H., Ruzov, A., Wilm, M., Georgiev, G., et al. (2001). The p120 catenin partner Kaiso is a DNA methylation-dependent transcriptional repressor. Genes Dev. 15, 1613-1618. doi: 10.1101/gad. 198501

Prokhortchouk, A., Sansom, O., Selfridge, J., Caballero, I. M., Salozhin, S., Aithozhina, D., et al. (2006). Kaiso-deficient mice show resistance to intestinal cancer. Mol. Cell. Biol. 26, 199-208. doi: 10.1128/MCB.26.1.199-208.2006

Qin, W., Leonhardt, H., and Pichler, G. (2011). Regulation of DNA methyltransferase 1 by interactions and modifications. Nucleus 2, 392-402. doi: 10.4161/nucl.2.5.17928

Qiu, C., Sawada, K., Zhang, X., and Cheng, X. (2002). The PWWP domain of mammalian DNA methyltransferase Dnmt3b defines a new family of DNAbinding folds. Nat. Struct. Biol. 9, 217-224. doi: 10.1038/nsb759

Rais, Y., Zviran, A., Geula, S., Gafni, O., Chomsky, E., Viukov, S., et al. (2013). Deterministic direct reprogramming of somatic cells to pluripotency. Nature 502, 65-70. doi: 10.1038/nature 12587

Rajakumara, E., Wang, Z., Ma, H., Hu, L., Chen, H., Lin, Y., et al. (2011). PHD finger recognition of unmodified histone H3R2 links UHRF1 to regulation of euchromatic gene expression. Mol. Cell. 43, 275-284. doi: 10.1016/j.molcel.2011.07.006

Ramocki, M. B., Peters, S. U., Tavyev, Y. J., Zhang, F., Carvalho, C. M., Schaaf, C. P., et al. (2009). Autism and other neuropsychiatric symptoms are prevalent in individuals with MeCP2 duplication syndrome. Ann. Neurol. 66, 771-782. doi: $10.1002 /$ ana. 21715

Razin, A., and Cedar, H. (1977). Distribution of 5-methylcytosine in chromatin. Proc. Natl. Acad. Sci. U.S.A. 74, 2725-2728. doi: 10.1073/pnas.74.7.2725

Rett, A. (1966). [On an until now unknown disease of a congenital metabolic disorder]. Krankenschwester 19, 121-122.

Reynolds, N., Latos, P., Hynes-Allen, A., Loos, R., Leaford, D., O’Shaughnessy, A., et al. (2012). NuRD suppresses pluripotency gene expression to promote transcriptional heterogeneity and lineage commitment. Cell Stem Cell 10, 583594. doi: 10.1016/j.stem.2012.02.020

Riccio, A., Aaltonen, L. A., Godwin, A. K., Loukola, A., Percesepe, A., Salovaara, R., et al. (1999). The DNA repair gene MBD4 (MED1) is mutated in human carcinomas with microsatellite instability. Nat. Genet. 23, 266-268. doi: $10.1038 / 15443$

Roll, J. D., Rivenbark, A. G., Jones, W. D., and Coleman, W. B. (2008). DNMT3b overexpression contributes to a hypermethylator phenotype in human breast cancer cell lines. Mol. Cancer 7, 15. doi: 10.1186/1476-4598-7-15

Roloff, T. C., Ropers, H. H., and Nuber, U. A. (2003). Comparative study of methyl-CpG-binding domain proteins. BMC Genomics 4:1. doi: 10.1186/14712164-4-1

Rothbart, S. B., Krajewski, K., Nady, N., Tempel, W., Xue, S., Badeaux, A. I., et al. (2012). Association of UHRF1 with methylated H3K9 directs the maintenance of DNA methylation. Nat. Struct. Mol. Biol. 19, 1155-1160. doi: 10.1038/nsmb.2391

Rottach, A., Frauer, C., Pichler, G., Bonapace, I. M., Spada, F., and Leonhardt, H. (2010). The multi-domain protein Np95 connects DNA methylation and histone modification. Nucleic Acids Res. 38, 1796-1804. doi: 10.1093/nar/gkp1152
Rountree, M. R., Bachman, K. E., and Baylin, S. B. (2000). DNMT1 binds HDAC2 and a new co-repressor, DMAP1, to form a complex at replication foci. Nat. Genet. 25, 269-277. doi: 10.1038/77023

Rudenko, A., Dawlaty, M. M., Seo, J., Cheng, A. W., Meng, J., Le, T., et al. (2013). Tet1 is critical for neuronal activity-regulated gene expression and memory extinction. Neuron 79, 1109-1122. doi: 10.1016/j.neuron.2013.08.003

Saito, M., and Ishikawa, F. (2002). The mCpG-binding domain of human MBD3 does not bind to $\mathrm{mCpG}$ but interacts with $\mathrm{NuRD} / \mathrm{Mi} 2$ components $\mathrm{HDAC} 1$ and MTA2. J. Biol. Chem. 277, 35434-35439. doi: 10.1074/jbc.M203455200

Sarraf, S. A., and Stancheva, I. (2004). Methyl-CpG binding protein MBD1 couples histone $\mathrm{H} 3$ methylation at lysine 9 by SETDB1 to DNA replication and chromatin assembly. Mol. Cell. 15, 595-605. doi: 10.1016/j.molcel.2004.06.043

Sasai, N., Matsuda, E., Sarashina, E., Ishida, Y., and Kawaichi, M. (2005). Identification of a novel BTB-zinc finger transcriptional repressor, CIBZ, that interacts with CtBP corepressor. Genes Cells 10, 871-885. doi: 10.1111/j.13652443.2005.00885.x

Schermelleh, L., Haemmer, A., Spada, F., Rosing, N., Meilinger, D., Rothbauer, U., et al. (2007). Dynamics of Dnmtl interaction with the replication machinery and its role in postreplicative maintenance of DNA methylation. Nucleic Acids Res. 35, 4301-4312. doi: 10.1093/nar/gkm432

Schlegel, J., Guneysu, S., and Mennel, H. D. (2002). Expression of the genes of methyl-binding domain proteins in human gliomas. Oncol. Rep. 9, 393-395.

Schneider, K., Fuchs, C., Dobay, A., Rottach, A., Qin, W., Wolf, P., et al. (2013). Dissection of cell cycle-dependent dynamics of Dnmtl by FRAP and diffusioncoupled modeling. Nucleic Acids Res. 41, 4860-4876. doi: 10.1093/nar/gkt191

Shahbazian, M., Young, J., Yuva-Paylor, L., Spencer, C., Antalffy, B., Noebels, J., et al. (2002). Mice with truncated MeCP2 recapitulate many Rett syndrome features and display hyperacetylation of histone H3. Neuron 35, 243-254. doi: 10.1016/S0896-6273(02)00768-7

Sharif, J., Muto, M., Takebayashi, S., Suetake, I., Iwamatsu, A., Endo, T. A., et al. (2007). The SRA protein Np95 mediates epigenetic inheritance by recruiting Dnmt1 to methylated DNA. Nature 450, 908-912. doi: 10.1038/nature06397

Shibayama, A., Cook, E. H. Jr., Feng, J., Glanzmann, C., Yan, J., Craddock, N., et al. (2004). MECP2 structural and 3'-UTR variants in schizophrenia, autism and other psychiatric diseases: a possible association with autism. Am. J. Med. Genet. B Neuropsychiatr. Genet. 128B, 50-53. doi: 10.1002/ajmg.b.30016

Shimbo, T., Du, Y., Grimm, S. A., Dhasarathy, A., Mav, D., Shah, R. R., et al. (2013). MBD3 localizes at promoters, gene bodies and enhancers of active genes. PLoS Genet. 9:e1004028. doi: 10.1371/journal.pgen.1004028

Skene, P. J., Illingworth, R. S., Webb, S., Kerr, A. R., James, K. D., Turner, D. J., et al. (2010). Neuronal MeCP2 is expressed at near histone-octamer levels and globally alters the chromatin state. Mol. Cell. 37, 457-468. doi: 10.1016/j.molcel.2010.01.030

Song, J., Rechkoblit, O., Bestor, T. H., and Patel, D. J. (2011). Structure of DNMT1-DNA complex reveals a role for autoinhibition in maintenance DNA methylation. Science 331, 1036-1040. doi: 10.1126/science.1195380

Song, J., Teplova, M., Ishibe-Murakami, S., and Patel, D. J. (2012). Structure-based mechanistic insights into DNMT1-mediated maintenance DNA methylation. Science 335, 709-712. doi: 10.1126/science. 1214453

Spruijt, C. G., Gnerlich, F., Smits, A. H., Pfaffeneder, T., Jansen, P. W., Bauer, C., et al. (2013). Dynamic readers for 5-(hydroxy)methylcytosine and its oxidized derivatives. Cell 152, 1146-1159. doi: 10.1016/j.cell.2013.02.004

Stancheva, I., Collins, A. L., Van den Veyver, I. B., Zoghbi, H., and Meehan, R. R. (2003). A mutant form of MeCP2 protein associated with human Rett syndrome cannot be displaced from methylated DNA by notch in Xenopus embryos. Mol. Cell. 12, 425-435. doi: 10.1016/S1097-2765(03)00276-4

Strichman-almashanu, L. Z., Lee, R. S., Onyango, P. O., Perlman, E., Flam, F., Frieman, M. B., et al. (2002). A genome-wide screen for normally methylated human cpg islands that can identify novel imprinted genes a genome-wide screen for normally methylated human cpg islands that can identify novel imprinted genes. Genome Res 12, 543-554. doi: 10.1101/gr.224102

Su, L. K., Kinzler, K. W., Vogelstein, B., Preisinger, A. C., Moser, A. R., Luongo, C., et al. (1992). Multiple intestinal neoplasia caused by a mutation in the murine homolog of the APC gene. Science 256, 668-670. doi: 10.1126/science.256.5060.1114-c

Suetake, I., Shinozaki, F., Miyagawa, J., Takeshima, H., and Tajima, S. (2004). DNMT3L stimulates the DNA methylation activity of Dnmt3a and 
Dnmt3b through a direct interaction. J. Biol. Chem. 279, 27816-27823. doi: 10.1074/jbc.M400181200

Suter, C. M., Martin, D. I., and Ward, R. L. (2004). Hypomethylation of L1 retrotransposons in colorectal cancer and adjacent normal tissue. Int. J. Colorectal. Dis. 19, 95-101. doi: 10.1007/s00384-003-0539-3

Szulwach, K. E., Li, X., Li, Y., Song, C. X., Wu, H., Dai, Q., et al. (2011). 5-hmCmediated epigenetic dynamics during postnatal neurodevelopment and aging. Nat. Neurosci. 14, 1607-1616. doi: 10.1038/nn.2959

Tahiliani, M., Koh, K. P., Shen, Y., Pastor, W. A., Bandukwala, H., Brudno, Y., et al. (2009). Conversion of 5-methylcytosine to 5-hydroxymethylcytosine in mammalian DNA by MLL partner TET1. Science 324, 930-935. doi: 10.1126/science.1170116

Tardy-Planechaud, S., Fujimoto, J., Lin, S. S., and Sowers, L. C. (1997). Solid phase synthesis and restriction endonuclease cleavage of oligodeoxynucleotides containing 5-(hydroxymethyl)-cytosine. Nucleic Acids Res. 25, 553-559. doi: 10.1093/nar/25.3.553

Tatton-Brown, K., Seal, S., Ruark, E., Harmer, J., Ramsay, E., Del Vecchio Duarte, S., et al. (2014). Mutations in the DNA methyltransferase gene DNMT3A cause an overgrowth syndrome with intellectual disability. Nat. Genet. 46, 385-388. doi: 10.1038/ng.2917

Traynor, J., Agarwal, P., Lazzeroni, L., and Francke, U. (2002). Gene expression patterns vary in clonal cell cultures from Rett syndrome females with eight different MECP2 mutations. BMC Med. Genet. 3:12. doi: 10.1186/1471-23503-12

Tsukada, Y., Fang, J., Erdjument-Bromage, H., Warren, M. E., Borchers, C. H., Tempst, P., et al. (2006). Histone demethylation by a family of JmjC domain-containing proteins. Nature 439, 811-816. doi: 10.1038/nature 04433

Tucker, K. L., Talbot, D., Lee, M. A., Leonhardt, H., and Jaenisch, R. (1996). Complementation of methylation deficiency in embryonic stem cells by a DNA methyltransferase minigene. Proc. Natl. Acad. Sci. U.S.A. 93, 12920-12925. doi: 10.1073/pnas.93.23.12920

Tudor, M., Akbarian, S., Chen, R. Z., and Jaenisch, R. (2002). Transcriptional profiling of a mouse model for Rett syndrome reveals subtle transcriptional changes in the brain. Proc. Natl. Acad. Sci. U.S.A. 99, 15536-15541. doi: 10.1073/pnas.242566899

Uchimura, Y., Ichimura, T., Uwada, J., Tachibana, T., Sugahara, S., Nakao, M., et al. (2006). Involvement of SUMO modification in MBD1- and MCAF1mediated heterochromatin formation. J. Biol. Chem. 281, 23180-23190. doi: 10.1074/jbc.M602280200

Unoki, M., Nishidate, T., and Nakamura, Y. (2004). ICBP90, an E2F-1 target, recruits $\mathrm{HDAC} 1$ and binds to methyl-CpG through its SRA domain. Oncogene 23, 7601-7610. doi: 10.1038/sj.onc. 1208053

Vella, P., Scelfo, A., Jammula, S., Chiacchiera, F., Williams, K., Cuomo, A., et al. (2013). Tet proteins connect the O-Linked $\mathrm{N}$-acetylglucosamine transferase Ogt to chromatin in embryonic stem cells. Mol. Cell 49, 645-656. doi: 10.1016/j.molcel.2012.12.019

Vincent, J. J., Huang, Y., Chen, P.-Y., Feng, S., Calvopiña, J. H., Nee, K., et al. (2013). Stage-specific roles for Tet1 and Tet2 in DNA demethylation in primordial germ cells. Cell Stem Cell 12, 470-478. doi: 10.1016/j.stem.2013. 01.016

Wade, P. A., Gegonne, A., Jones, P. L., Ballestar, E., Aubry, F., and Wolffe, A. P. (1999). Mi-2 complex couples DNA methylation to chromatin remodelling and histone deacetylation. Nat. Genet. 23, 62-66. doi: 10.1038/12664

Wakefield, R. I., Smith, B. O., Nan, X., Free, A., Soteriou, A., Uhrin, D., et al. (1999). The solution structure of the domain from MeCP2 that binds to methylated DNA. J. Mol. Biol. 291, 1055-1065. doi: 10.1006/jmbi.1999.3023

Walter, M. J., Ding, L., Shen, D., Shao, J., Grillot, M., McLellan, M., et al. (2011). Recurrent DNMT3A mutations in patients with myelodysplastic syndromes. Leukemia 25, 1153-1158. doi: 10.1038/leu.2011.44

Wang, C., Shen, J., Yang, Z., Chen, P., Zhao, B., Hu, W., et al. (2011). Structural basis for site-specific reading of unmodified R2 of histone $\mathrm{H} 3$ tail by UHRF1 PHD finger. Cell Res. 21, 1379-1382. doi: 10.1038/cr.2011.123

Watanabe, D., Suetake, I., Tada, T., and Tajima, S. (2002). Stage- and cell-specific expression of Dnmt3a and Dnmt3b during embryogenesis. Mech. Dev. 118, 187-190. doi: 10.1016/S0925-4773(02)00242-3

Watanabe, D., Suetake, I., Tajima, S., and Hanaoka, K. (2004). Expression of Dnmt3b in mouse hematopoietic progenitor cells and spermatogonia at specific stages. Gene Expr. Patterns 5, 43-49. doi: 10.1016/j.modgep.2004. 06.008

Weber, A., Marquardt, J., Elzi, D., Forster, N., Starke, S., Glaum, A., et al. (2008). Zbtb4 represses transcription of P21CIP1 and controls the cellular response to p53 activation. EMBO J. 27, 1563-1574. doi: 10.1038/emboj.2008.85

Welling, M., Chen, H.-H., Muñoz, J., Musheev, M. U., Kester, L., Junker, J. P., et al. (2015). DAZL regulates Tet 1 translation in murine embryonic stem cells. EMBO Rep. 16, 791-802. doi: 10.15252/embr.201540538

Whyte, W. A., Bilodeau, S., Orlando, D. A., Hoke, H. A., Frampton, G. M., Foster, C. T., et al. (2012). Enhancer decommissioning by LSD1 during embryonic stem cell differentiation. Nature 482, 221-225. doi: 10.1038/nature10805

Williams, K., Christensen, J., Pedersen, M. T., Johansen, J. V., Cloos, P. A., Rappsilber, J., et al. (2011). TET1 and hydroxymethylcytosine in transcription and DNA methylation fidelity. Nature 473, 343-348. doi: 10.1038/nature10066

Winkelmann, J., Lin, L., Schormair, B., Kornum, B. R., Faraco, J., Plazzi, G., et al. (2012). Mutations in DNMT1 cause autosomal dominant cerebellar ataxia, deafness and narcolepsy. Hum. Mol. Genet. 21, 2205-2210. doi: $10.1093 / \mathrm{hmg} / \mathrm{dds} 035$

Woo, H. R., Pontes, O., Pikaard, C. S., and Richards, E. J. (2007). VIM1, a methylcytosine-binding protein required for centromeric heterochromatinization. Genes Dev. 21, 267-277. doi: 10.1101/gad.1512007

Woodcock, C. L. (2006). Chromatin architecture. Curr. Opin. Struct. Biol. 16, 213-220. doi: 10.1016/j.sbi.2006.02.005

Wossidlo, M., Nakamura, T., Lepikhov, K., Marques, C. J., Zakhartchenko, V., Boiani, M., et al. (2011). 5-Hydroxymethylcytosine in the mammalian zygote is linked with epigenetic reprogramming. Nat. Commun. 2:241. doi: $10.1038 /$ ncomms 1240

Xie, Z. H., Huang, Y. N., Chen, Z. X., Riggs, A. D., Ding, J. P., Gowher, H., et al. (2006). Mutations in DNA methyltransferase DNMT3B in ICF syndrome affect its regulation by DNMT3L. Hum. Mol. Genet. 15, 1375-1385. doi: $10.1093 / \mathrm{hmg} / \mathrm{ddl} 059$

Xu, G. L., Bestor, T. H., Bourc'His, D., Hsieh, C. L., Tommerup, N., Bugge, M., et al. (1999). Chromosome instability and immunodeficiency syndrome caused by mutations in a DNA methyltransferase gene. Nature 402, 187-191. doi: $10.1038 / 46052$

Xu, W., Yang, H., Liu, Y., Yang, Y., Wang, P., Kim, S. H., et al. (2011). Oncometabolite 2-hydroxyglutarate is a competitive inhibitor of $\alpha$-ketoglutarate-dependent dioxygenases. Cancer Cell 19, 17-30. doi: 10.1016/j.ccr.2010.12.014

Xu, Y., Wu, F., Tan, L., Kong, L., Xiong, L., Deng, J., et al. (2011). Genomewide regulation of $5 \mathrm{hmC}, 5 \mathrm{mC}$, and gene expression by Tet1 hydroxylase in mouse embryonic stem cells. Mol. Cell 42, 451-464. doi: 10.1016/j.molcel.2011. 04.005

Xu, Y., Xu, C., Kato, A., Tempel, W., Abreu, J. G., Bian, C., et al. (2012). Tet3 CXXC domain and dioxygenase activity cooperatively regulate key genes for xenopus eye and neural development. Cell 151, 1200-1213. doi: 10.1016/j.cell.2012.11.014

Yamaguchi, S., Hong, K., Liu, R., Shen, L., Inoue, A., Diep, D., et al. (2012). Tet1 controls meiosis by regulating meiotic gene expression. Nature 492, 443-447. doi: 10.1038/nature11709

Yamaguchi, S., Shen, L., Liu, Y., Sendler, D., and Zhang, Y. (2013). Role of Tet1 in erasure of genomic imprinting. Nature 504, 460-464. doi: 10.1038/nature 12805

Yasui, D. H., Peddada, S., Bieda, M. C., Vallero, R. O., Hogart, A., Nagarajan, R. P., et al. (2007). Integrated epigenomic analyses of neuronal MeCP2 reveal a role for long-range interaction with active genes. Proc. Natl. Acad. Sci. U.S.A. 104, 19416-19421. doi: 10.1073/pnas.0707442104

Yildirim, O., Li, R., Hung, J. H., Chen, P. B., Dong, X., Ee, L. S., et al. (2011). Mbd3/NURD complex regulates expression of 5-hydroxymethylcytosine marked genes in embryonic stem cells. Cell 147, 1498-1510. doi: 10.1016/j.cell.2011.11.054

Yoder, J. A., and Bestor, T. H. (1998). A candidate mammalian DNA methyltransferase related to pmtlp of fission yeast. Hum. Mol. Genet. 7, 279284. doi: 10.1093/hmg/7.2.279

Yoder, J. A., Yen, R. W., Vertino, P. M., Bestor, T. H., and Baylin, S. B. (1996). New 5' regions of the murine and human genes for DNA (cytosine-5)-methyltransferase. J. Biol. Chem. 271, 31092-31097. doi: $10.1074 /$ jbc. 271.49 .31092 
Yoon, H. G., Chan, D. W., Reynolds, A. B., Qin, J., and Wong, J. (2003). N-CoR mediates DNA methylation-dependent repression through a methyl CpG binding protein Kaiso. Mol. Cell 12, 723-734. doi: 10.1016/j.molcel.2003.08.008

Yu, C., Zhang, Y. L., Pan, W. W., Li, X. M., Wang, Z. W., Ge, Z. J., et al. (2013). CRL4 complex regulates mammalian oocyte survival and reprogramming by activation of TET proteins. Science 342, 1518-1521. doi: 10.1126/science. 1244587

Zhang, H., Zhang, X., Clark, E., Mulcahey, M., Huang, S., and Shi, Y. G. (2010). TET1 is a DNA-binding protein that modulates DNA methylation and gene transcription via hydroxylation of 5-methylcytosine. Cell Res. 20, 1390-1393. doi: $10.1038 /$ cr.2010.156

Zhang, J., Gao, Q., Li, P., Liu, X., Jia, Y., Wu, W., et al. (2011). S phase-dependent interaction with DNMT1 dictates the role of UHRF1 but not UHRF2 in DNA methylation maintenance. Cell Res. 21, 1723-1739. doi: 10.1038/cr.2011.176

Zhang, P., Su, L., Wang, Z., Zhang, S., Guan, J., Chen, Y., et al. (2012). The involvement of 5-hydroxymethylcytosine in Active DNA demethylation in Mice. Biol. Reprod. 86, 104. doi: 10.1095/biolreprod.111.096073

Zhang, Q., Liu, X., Gao, W., Li, P., Hou, J., Li, J., et al. (2014). Differential regulation of the ten-eleven translocation (TET) family of dioxygenases by O-linked beta$\mathrm{N}$-acetylglucosamine transferase (OGT). J. Biol. Chem. 289, 5986-5996. doi: 10.1074/jbc.M113.524140

Zhang, R. R., Cui, Q. Y., Murai, K., Lim, Y. C., Smith, Z. D., Jin, S., et al. (2013). Tet1 regulates adult hippocampal neurogenesis and cognition. Cell Stem Cell 13, 237-245. doi: 10.1016/j.stem.2013.05.006
Zhang, Y., Ng, H. H., Erdjument-Bromage, H., Tempst, P., Bird, A., and Reinberg, D. (1999). Analysis of the NuRD subunits reveals a histone deacetylase core complex and a connection with DNA methylation. Genes Dev. 13, 1924-1935.

Zhao, X., Ueba, T., Christie, B. R., Barkho, B., McConnell, M. J., Nakashima, K., et al. (2003). Mice lacking methyl-CpG binding protein 1 have deficits in adult neurogenesis and hippocampal function. Proc. Natl. Acad. Sci. U.S.A. 100, 6777-6782. doi: 10.1073/pnas.1131928100

Zhou, Z., Qin, J., Tang, J., Li, B., Geng, Q., Jiang, W., et al. (2013). Downregulation of $\mathrm{MeCP}_{2}$ in Hirschsprung's disease. J. Pediatr. Surg. 48, 2099-2105. doi: 10.1016/j.jpedsurg.2013.07.011

Zocchi, L., and Sassone-Corsi, P. (2012). SIRT1-mediated deacetylation of $\mathrm{MeCP}_{2}$ contributes to BDNF expression. Epigenetics 7, 695-700. doi: 10.4161/epi.20733

Conflict of Interest Statement: The authors declare that the research was conducted in the absence of any commercial or financial relationships that could be construed as a potential conflict of interest.

Copyright (c) 2016 Ludwig, Zhang and Cardoso. This is an open-access article distributed under the terms of the Creative Commons Attribution License (CC BY). The use, distribution or reproduction in other forums is permitted, provided the original author(s) or licensor are credited and that the original publication in this journal is cited, in accordance with accepted academic practice. No use, distribution or reproduction is permitted which does not comply with these terms. 